\title{
住宅と生活からみるシニアタウン化した住宅地における 自立高齢期夫婦の居住スタイルに関する考察
}

\author{
別荘地と定住地の二面性を有するシニアタウン化した住宅地における高齢者の居住環境に関する研究 その 3

\section{LIFESTYLES AND ACTIVITIES OF INDEPENDENT ELDERLY COUPLES AT SENIOR CITIZEN TOWNS AS VIEWED FROM THEIR HOUSING AND LIVING STYLES}

A study on the residential environment of elderly settlers of a residential area that changed into a town for senior citizens and that has bilateral character of a villa and settlement Part 3

\author{
竹田 喜美子*，番場 美恵子** \\ Kimiko TAKEDA and Mieko BAMBA
}

\begin{abstract}
The purpose of this study is to investigate the living styles of independent elderly couples at residential areas that changed into a town for senior citizens. The authors were able to clarify the following: 1) Most of the seniors' life activities are spent in spacious living-dining-kitchen (LDK) rooms and on villa terraces that can be characterized as simple, compact, and open. 2) In terms of life activities, different hobbies and relaxation modes provide seniors with individual independence, while shared dining and housekeeping chores help them reaffirm their continuance as couples. 3) The most important aspect of the husband and wife relationship is a proper balance between independence and cooperation with each other. In other words, individual spirit and independence must be respected. 4) When viewed from "the silver stage" (age level), the people of the zero to second stage (55 to 69 years old) lead the most active lives, the third stage elders (70 to 74 years old) are in a period of transition, and the fourth to fifth stage elders (more than 75 years old) tend to live placid lives. Thus, as their years increase, the lifestyle activities of seniors tend to pass through three stages.
\end{abstract}

keywords: Villa, Settlement, Town for senior citizens, Living activities, Husband and wife relationship, Lifestyles and activites 別荘地，定住，シニアタウン，住まい方，夫婦関係，居住スタイル

1.はじめに

1-1 研究目的

本研究は, 別荘地と定住地の二面性を有するシニアタウン化した 住宅地注 ${ }^{1)}$ に定住する注 ${ }^{2)}$ 高齢者を対象に, 居住様態を多角的に分 析し, 高齢者の自立生活及び居住継続を保障し，住宅地として持続 可能な居住環境に関する知見を得ることを目的とする。

既報その 1 では，開発プロセスと立地環境および管理体制の視 点から, シニアタウン化した住宅地の発展・継続を可能にするく居 住システム $>$ を論考し，その 2 では，新たな人間関係を構築するく 居住ネットワーク>の分析から, 居住の安心と安全を確保するため の地域コミュニティの形成要件を考察した。

本報その 3 では，住宅内の空間抢よびそこでの住まい方に着目す る。一般に，別荘は豊かな自然に囲まれた地域に立地し，日常生活 とは別に避暑や避寒，休養などの目的で過ごす住宅のことを指す。 そこでは身体や思考を拘束しない自由で開放的な生活が展開され， それが高齢者の居住環境として求められる条件と符合する空間にな るのはでないかと仮定した。その 3 では，このような立地に建設さ れる住宅の特性および住まい方の関係から，自立した高齢夫婦の< 居住スタイル>像を抽出し, 高齢期の生活に相応した住空間および 夫婦関係について考察する。また，年齢の上昇に伴う住まい方の変
容過程を捉える。そして最後に，シニアタウン化した住宅地における 高齢者の居住環境に関する一連の研究の総括を行う。

\section{1-2 研究方法}

研究方法は既報と同様，アンケート調査から量的傾向を把握し， ヒアリング調查から質的傾向を分析する。本報ではとくに事例にも 注目する。

本報で取り上げる＜居住スタイル $>$ とは,「人間」一「空間」一「生活」 の三者によって形成される居住様態を指す。「人間」は高齢夫婦,「空 間」は自然環境に恵まれた敷地に建つ別荘注 ${ }^{3)}$,「生活」は主に住戸 内で展開される生活行為を対象とする。

論文の構成は，まず住宅プランの特徴をまとめ，次に空間からみ た住まい方，すなわち各生活行為が展開される空間の使われ方を分 析する。そして時間からみた住まい方, すなわち各生活行為が行わ れる時間帯と時間量から生活時間の配分を分析する。最後に夫婦関 係からみた住まい方，すなわち夫婦間における日常生活の有り様を 通して, 精神的自立と依存の視点からみた夫婦関係のパターンを導 き出す。

高齢期にみられる余暇時間および在宅時間の拡大などを考慮し, 生活行為の領域を以下のように分類する (表 1)。生活行為をコミュ ニケーションとプライバシーを軸に, 接客一食事一家事一くつろぎ
* 昭和女子大学 名誉教授 ·博士 (学術)

** 昭和女子大学環境デザイン学科 専任講師・博士(学術)
Prof. Emeritus, Showa Women's University, Ph. D.

Lect., Dept. of Environmental Science and Design, Showa Women's University, Ph. D. 
表 1 高齢期の生活行為の分布

\begin{tabular}{|c|c|c|c|c|}
\hline 生活軸 & \multicolumn{2}{|c|}{ コミュニケーション } & \multicolumn{2}{|c|}{ プライバシー } \\
\hline 生活行為 & 接客 & 食事·家事 & くつろぎ·趣味 & 就寝 \\
\hline \multirow{4}{*}{ 生活領域 } & $\begin{array}{c}\text { 夫婦以外の } \\
\text { 他者との } \\
\text { 共有行為 }\end{array}$ & $\begin{array}{c}\text { 夫婦との } \\
\text { 共有行為 }\end{array}$ & $\begin{array}{c}\text { 心の癒しや自己 } \\
\text { 実現のための } \\
\text { 個人行為 }\end{array}$ & $\begin{array}{c}\text { 身体のの癒しのた } \\
\text { めの個人行為 }\end{array}$ \\
\cline { 2 - 6 } & 客 & 共 & 個 & 㾛 \\
\hline
\end{tabular}

（居）一趣味一就寝に分類し, 生活領域として夫婦以外の他者との 共有行為を「客」, 夫婦との共有行為を「共」, 心の癒しや自己実現 のための個人行為を「個」, 身体の癒しのための個人行為を「葠」 に大別する。

\section{1-3 既往研究}

高齢期の居住スタイル，住まい方に関する既往研究をみると，要 介護高齢者を対象にした論文が主で，自立高齢者を扱ったものはそ れほど多くない。

関連した論文として, 加藤ら ${ }^{1)}$ は生活スタイルと住まい方からみた 団地居住高齢者の環境整備に関する考察のなかで, 生活の (身体的) 自立依存と外出頻度の多少の 2 軸で生活スタイルを分類し, 高齢者 居住のための住宅の在り方について考察している。沢田 ${ }^{2)}$ は熟年・ 高齢期におけるライフスタイルと住まい方の特徵として, 熟年期 (60 歳代 ) を自立可能なステージ, 高齢期（70 歳以上）を自立困難なス テージと規定し，中年期も視野に入れて分析している。加茂ら ${ }^{3)}$ は 居住実験をとおして，「エンプティ・ネスト」期への移行に伴う住ま い方と住ニーズの変化をみている。それぞれ自立高齢者の夫婦の住 まいとして示唆に富むが, 対象が集合住宅居住であり, 研究目的も それぞれ異なる。

本研究の独自性は，(1)自然環境に恵まれた別荘地（戸建住宅）に 移住し, 退職後の生活を送る高齢者を対象にしていること, (2)自立 高齢期夫婦の居住スタイルを, 人間一空間一生活の 3 つの様態か ら複合的に分析していること, (3) 60 歳以上を 5 歳ごとに分類する シルバーステージ別注4) に居住スタイルを把握していることである。 なお，自立高齢者を対象としているのは，近年注目されている健康 寿命の延伸により, 健康で活動的な高齢夫婦世帯が増加する傾向に あることから，この層の居住スタイルを捉え，居住環境を整備する ことが重要と考えるからである。

\section{1-4 調査概要}

調查対象, 調查方法は既報と同様である主 5)。住まい方に関しては, 各住戸における図面拉よび家具配置の採集を行い，住戸内で行われ る生活行為をプロットした。

調査対象戸数のベースは, 図面採集ができた千ヶ滝 47 戸, かし ま野 38 戸，美奈宜の杜 53 戸の計 138 戸である。住宅特性の分析 以外は，詳細な住まい方が把握できた夫婦世帯に限定する。取り上 げる内容によって分析対象数が変動するため, その都度戸数を示す。

調査内容は, 現住宅についての概況 (建築年代, 敷地面積, 床面積, 間取りと各部屋の使われ方), 住まい方 (就寝以外最も長く居る部 屋での行為, 接客・就寝・家事の状況), 日常生活 (外出・買い物, 生活上のルール), 生活時間表 (1 日の大半を家で過ごす日の生活 の流れ）などである。調查時期は, 千ヶ滝は 2009 年 9 月, かしま 野は 2007 年 8 月, 美奈宜の杜は 2008 年 8 月である。

\section{2．居住者属性と住宅特性}

\section{2-1 居住者属性}

調査対象の年齢は 60 代が中心で, 平均年齢は 60 歳後半である。 家族構成は夫婦のみが約 8 割を占める。就業状況は, 無職が夫婦 とも約 8 割 (千ヶ滝のみ夫の無職は 5 割) である。居住年数は 5 〜 6 年が中心であるが, 3 カ月から 20 年超まで幅がある。身体状況を みると, 基本的に自立しているが, 持病（高血圧や糖尿病, 関節痛) を抱える人が $2 \sim 3$ 割程度存在する。移住理由は,「新しい生活を 始めたい」「定年退職を機に」「夫婦でのんびり暮らしたい」「趣味に 没頭したい」がみられる主6)

\section{2-2 住宅特性}

調查対象の 3 簓所は，高原にある高級別荘地（千ヶ滝）と海浜に ある大衆別荘地（かしま野）ならびにシニアタウン（美奈宜の杜）に 分類できる。それぞれ住宅特性が異なるため, 対象地ごとに面積お よびプラン傾向を分析する。面積傾向は, 敷地面積, 床面積, LDK 面積及びテラス面積から (表 2), プラン傾向は, 間取りタイプ, 階数, 和室数（表 3, 表 4) から把握する。

千ヶ滝の面積傾向をみると, 平均敷地面積が $935.6 \mathrm{~m}^{2}$, 床面積 が $131.1 \mathrm{~m}^{2}$, LDK 面積が $40.3 \mathrm{~m}^{2}$ といずれも広い。床面積に対する LDK 面積の割合は 31.9 \%になる。テラス面積も 19.0 m広い。プ ラン傾向をみると, 階数は 2 階建が多く, そのうち吹抜けは 6 割強 を占める。プランタイプは 3 ～ $4 \mathrm{LDK}$ が中心で, LDK タイプは LDK ワンルームが 35 戸 $(74.5 \%)$ で圧倒的に多く, 次いで LD・K が 8 戸 (17.0\%) である。和室は他の地域と比べ少ない。

かしま野の面積傾向をみると, 平均敷地面積は $367.8 \mathrm{~m}$ である が，床面積と LDK 面積が狭い。床面積に対するLDK 面積の割合 は $26.5 \%$ あ゙る。プラン傾向をみると, 階数は平家建が圧倒的に多 く, 2 階建の吹抜けは 3.5 割である。プランタイプは $2 \mathrm{LDK}$ が中心 で，LDK タイプは LDK ワンルームが 29 戸 (76.3\%) で圧倒的に多

表 2 敷地面積・床面積・LDK 面積・テラス面積

\begin{tabular}{|c|c|c|c|c|c|c|c|c|}
\hline & \multicolumn{2}{|c|}{ 敷地面積 $\mathrm{m}^{2}$} & \multicolumn{2}{|c|}{ 床面積 $\mathrm{m}^{2}$} & \multicolumn{2}{|c|}{ LDK面積 $\mathrm{m}^{2}$} & \multicolumn{2}{|c|}{ テラス面積 $\mathrm{m}^{2}$} \\
\hline & 最小〜最大 & 平均 & 最小〜最大 & 平均 & 最小〜最大 & 平均 & 最小 最大 & 平均 \\
\hline 全 体 & & 545.0 & & 111.2 & & 32.6 & & 13.5 \\
\hline 千ヶ滝 & $264 \sim 3300$ & 935.4 & $67.6 \sim 297$ & 131.1 & $13.4 \sim 90$ & 40.3 & $5.4 \sim 38.3$ & 19.1 \\
\hline かしま野 & $218 \sim 666$ & 367.8 & $36.3 \sim 214.5$ & 92.4 & $16.5 \sim 39.6$ & 24.5 & $1.5 \sim 47.6$ & 9.7 \\
\hline 美奈宜の杜 & $231 \sim 759$ & 331.8 & $71.7 \sim 165$ & 110.0 & $16.6 \sim 59.8$ & 32.9 & $3.3 \sim 65.8$ & 11.7 \\
\hline
\end{tabular}

表 3 間取りタイプ（戸数）

\begin{tabular}{|c|c|c|c|c|c|c|c|}
\hline & 戸数 & $1 \mathrm{LDK}$ & $2 \mathrm{LDK}$ & $3 \mathrm{LDK}$ & 4LDK & $5 \mathrm{LDK}$ & $6 \mathrm{LDK}$ \\
\hline \multirow{2}{*}{ 全 体 } & 138 & 9 & 52 & 46 & 29 & 1 & 1 \\
\hline & 100.0 & 6.5 & 37.7 & 33.3 & 21.0 & 0.7 & 0.7 \\
\hline \multirow{2}{*}{ 千ヶ滝 } & 47 & 1 & 13 & 16 & 16 & 0 & 1 \\
\hline & 100.0 & 2.1 & 27.7 & 34.0 & 34.0 & 0.0 & 2.1 \\
\hline \multirow{2}{*}{ かしま野 } & 38 & 7 & 18 & 9 & 3 & 1 & 0 \\
\hline & 100.0 & 18.4 & 47.4 & 23.7 & 7.9 & 2.6 & 0.0 \\
\hline \multirow{2}{*}{ 美奈宜の杜 } & 53 & 1 & 21 & 21 & 10 & 0 & 0 \\
\hline & 100.0 & 1.9 & 39.6 & 39.6 & 18.9 & 0.0 & 0.0 \\
\hline
\end{tabular}

表 4 階数と和室数（戸数）

\begin{tabular}{|c|c|c|c|c|c|c|c|c|c|c|c|}
\hline & \multirow{2}{*}{\multicolumn{2}{|c|}{ 戸 数 }} & \multicolumn{4}{|c|}{ 階 数 } & \multicolumn{5}{|c|}{ 和 室 } \\
\hline & & & & 平家建 & & 2階建 & O室 & 1室 & 2室 & 3室 & \\
\hline \multirow{2}{*}{ 計 } & 138 & & 78 & & 6 & & 44 & 71 & 20 & 3 & \\
\hline & & 100.0 & & 56.5 & & 43.5 & 31.9 & 51.4 & 14.5 & & 2.2 \\
\hline \multirow{2}{*}{ 千ヶ滝 } & 47 & & 15 & & 3 & & 27 & 15 & 5 & 0 & \\
\hline & & 100.0 & & 31.9 & & 68.1 & 57.4 & 31.9 & 10.6 & 0. & .0 \\
\hline \multirow{2}{*}{ かしま野 } & 38 & & 27 & & 1 & & 11 & 21 & 6 & 0 & \\
\hline & & 100.0 & & 71.1 & & 28.9 & 28.9 & 55.3 & 15.8 & 0. & .0 \\
\hline \multirow{2}{*}{ 美奈宜の杜 } & 53 & & 36 & & 1 & & 6 & 35 & 9 & 3 & \\
\hline & & 100.0 & & 67.9 & & 32.1 & 11.3 & 66.0 & 17.0 & 5. & 5.7 \\
\hline
\end{tabular}


く, 次いで $\mathrm{L} \cdot \mathrm{DK}$ が 4 戸, L $/ \mathrm{DK}$ が 3 戸である。和室は 1 室が 5.5 割で, 次いで 0 室が 3 割である。

美奈宜の杜の面積傾向をみると, 平均敷地面積が $331.8 \mathrm{~m}$, 床 面積が $110.0 \mathrm{~m}$ ， LDK 面積は $32.9 \mathrm{~m}$ である。床面積に対する LDK 面積の割合は $29.9 \%$ あるる。プラン傾向をみると, 階数は平家建 が多く, 2 階建の吹抜けは少ない。プランタイプは 2 2 LDK が中 心で, LDK タイプは LDK ワンルームが 23 戸 (43.4\%) で, 次いで $\mathrm{LD}$ K $(12$ 戸 $), \mathrm{LD} / \mathrm{K}(10$ 戸) である。和室は 1 室が 6.5 割, 2 室が 1.5 割強で和室が多い。

以上, 住宅プランの特性をまとめると, ひとつは床面積の割に居 室数が少ないことである(床面積の平均 $111.2 \mathrm{~m}^{2}$, 居室数の平均 3.75 室)。つまり機能がシンプルである注7)。次に, 平家建で, 敷地面積 に対して床面積の割合は低く, 面積がコンパクトである (平家建の 割合は $56.5 \%$, 敷地面積の平均は $545.0 \mathrm{~m}^{2}$ ) 注 8$)$ 。さらに, LDK は 面積が大きく, L と D と K のつながりや，隣室とのつながりがオー プンである。かつ吹抜けになることが多く, 水平・垂直方向に広が りをみせている (LDK 面積の平均は $32.6 \mathrm{~m}^{2}$, LDK のワンルーム型 は $63.0 \%$, 吹き抜けは 2 階建の 50.0\%)。室どうしは閉鎖的な仕 切りがなく開放的につながっている。つまり, 構成がオープンなの である。

一方, テラスの面積平均は $13.5 \mathrm{~m}$ で広い。また, 和室は, 全体 で 0 室が 3 割強, 1 室が 5 割強, 2 室は 1.5 割である。洋室が中 心のプランであるが, 和室も有する。

\section{3. 空間と生活の関係からみる居住スタイル}

本章では空間から住まい方をみていく。分析対象は夫婦のみ世 帯に限定し, 千ヶ滝 37 戸, かしま野 27 戸, 美奈宜の杜 46 戸の計 110 戸である。

3-1 空間からみた住まい方

生活行為を, 就寝, 趣味, くつろぎ, 食事, 接客の 5 つに分類し, それぞれの行為が行われる空間を把握する。

\section{1) 就寝空間}

夫婦同室は 84 戸(76.4\%), 別室は 26 戸(23.6\%)で, 移住前(20 戸）より別室の割合が若干増えている。また，「美奈宜の杜」は夫 婦別室が $34.8 \%$ と, 他の地域より別室の割合が高い。「別寝」になっ たのは, いびきがうるさい, 就寝時間が異なるなどの理由の他に, 移住したことにより, 夫婦二人の生活になって部屋に余裕ができたこ とも一要因となっている。寝室の和洋室の別をみると, 洋室が 109 室 (80.1\%) と圧倒的に多い。

\section{2) 趣味空間 (書斎やアトリエも含む)}

3 地域とも「趣味あり」は 9 割台である。そのうち, 趣味を自宅 で行う割合は「千ヶ滝」で 7 割,「かしま野」と「美奈宜の杜」は 4 割台である。自宅で行う趣味には, ガーデニング・読書・絵画・楽 器演奏・音楽鑑賞・陶芸・工芸があり, それ以外に夫では, 写真・ パソコン・囲碁があり, 妻では料理 (パンつくり・菓子つくり)・裁縫・ 手芸がある。趣味が行われる室をみると, LDK が 49 戸 (44.5\%), 趣味室が 50 戸 $(45.5 \%)$ と多く, その他には少数であるが, 寝室 11 戸 (10.0\%), 客間 9 戸 (8.2\%) もみられる（表 5)。とくに, 散 らかりや污れが生じる趣味, あるいは静寂を必要とするものは LDK 以外で行う傾向がある。なお, 趣味室のなかには, 別棟も 8 戸含まれ,
「かしま野」で多い（図 1)。また，「美奈宜の杜」は寝室が 7 戸と他 に比べ多いが, これは夫婦別寝の結果であると思われる。(図 2)。

夫婦が同室で趣味を行う住戸は 38 戸 (34.5\%) で, 共用の趣味 室は 8 戸で, LDK が 30 戸と多い。広い LDK では, 夫婦が枑い の趣味をしていても夫は L コーナー, 妻は D コーナーというように 拠点が異なるので気にならないという。移住理由の一つに,「趣味 に没頭したい」があり, 自宅でも趣味専用の室を持ち, 趣味行為も 活発であることがわかる。

\section{3）くつろぎ空間}

くつろぐとは, テレビを見たり新聞や雑誌を読んだり, 休息したり, おしゃべりしたりする行為を指す。夫婦で一緒に広いLDK でくつろ ぐことが一般的であるが, テラスや自室のこともある。リビングでは, イスやソファで腰掛けるイス坐が主であるが, 畳を敷いたり, または 「掘り炬燵」や「いろり」を設置したり, ユカ坐での生活を楽しんで いる住戸もみられる(図 3)。

\section{4) 食事空間}

ふだんはダイニングで食事を摂るが, 時にはブランチやバーベ キューあるいは喫茶の時にテラスを利用することがある（図 4)。

\section{5）接客空間}

高齢者にとって, 他者と接する接客行為は夫婦二人の単調な生活 からの変化という意味でも大切である。LDK 以外に接客空間を有す る住戸は 90 戸(81.8\%) で, 客間 (46 戸) と宿泊室 (54戸) がある。 両室保有している住戸は 18 戸である。とくに「千ヶ滝」では約 9 割 (33 戸) が宿泊室を設けている。各室の和洋室の別をみると, 客間 は和室が 42 戸で 9 割を占め, 宿泊室は和室 25 戸, 洋室 29 戸と半々 である。

来客の種類と頻度, 応対場所をみると, 隣人の場合, 頻度は週 1 〜2 回が多く, 応対場所は LDK か玄関あるいはテラスである。友 人の場合, 頻度は年 $1 \sim 2$ 回, 千ヶ滝は月 $1 \sim 2$ 回か年 $5 \sim 6$ 回 と多く, 応対場所は LDK か客間である。子ども・孫の場合, 頻度 は年 $5 \sim 6$ 回か年 $1 \sim 2$ 回に集中し, 応対場所は LDK を始めどの 部屋にも通す。親戚の場合, 年 $1 \sim 2$ 回で応対場所は LDK か客間 である (図 5)。また, シルバーステージ別にみると, stage0 〜 2 は友人, 子どもの来訪が多く, stage 3 になると隣人の来訪も増える (表 6 )。 stage $4 \sim 5$ では, 隣人や友人の来訪が少なくなる。

表 5 地域別趣味空間

\begin{tabular}{|c|c|c|c|c|c|c|c|c|}
\hline & & & & 趣呵 & & & & \\
\hline & 戸 & LDK & 小計 & 専用 & 共用 & 別棟 & 葠室 & 客間 \\
\hline 計 & 110 & 49 & 50 & 34 & 8 & 8 & 11 & 9 \\
\hline & & 44.5 & 45.5 & 30.9 & 7.3 & 7.3 & 10.0 & 8.2 \\
\hline 千ヶ滝 & 37 & 24 & 19 & 13 & 4 & 2 & 2 & 2 \\
\hline & & 64.9 & 51.4 & 35.1 & 10.8 & 5.4 & 5.4 & 5.4 \\
\hline かしま野 & 27 & $\begin{array}{ll}11 & \\
& 407\end{array}$ & 33. & 18.5 & 37 & 111 & $7{ }^{3}$ & 111 \\
\hline 美奈宜の杜 & 46 & 14 & 22 & 16 & 6.5 & 3 & 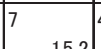 & 4 \\
\hline & & & & & 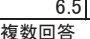 & 6.5 & $\frac{1}{\text { (上段:戸数 }}$ & $\begin{array}{r}8.7 \\
\text { 下段:\%) }\end{array}$ \\
\hline
\end{tabular}

表 6 シルバーステージ別来客の種類

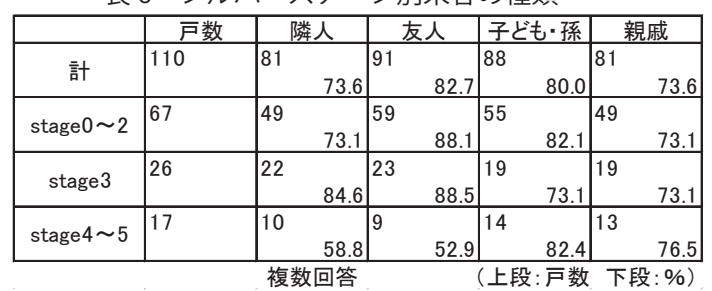




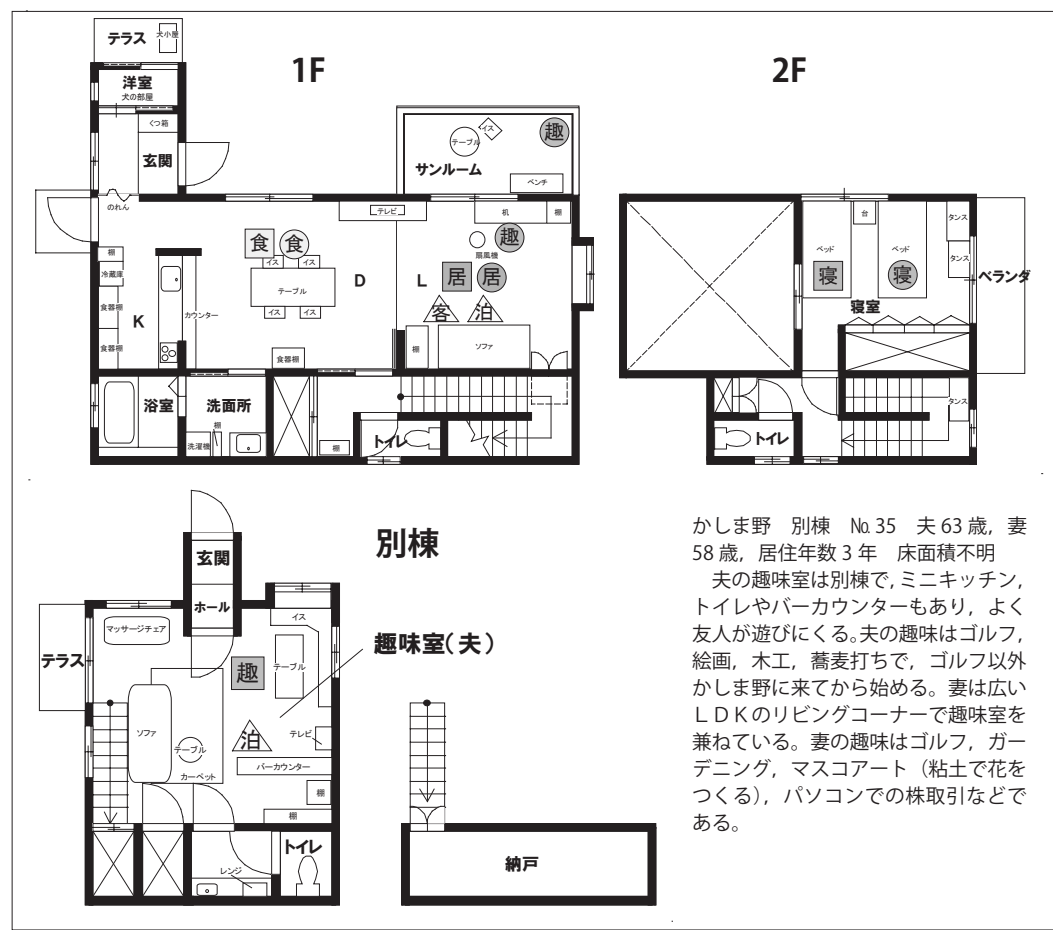

図 1 趣味空間 住まい方事例（かしま野 NO.35）

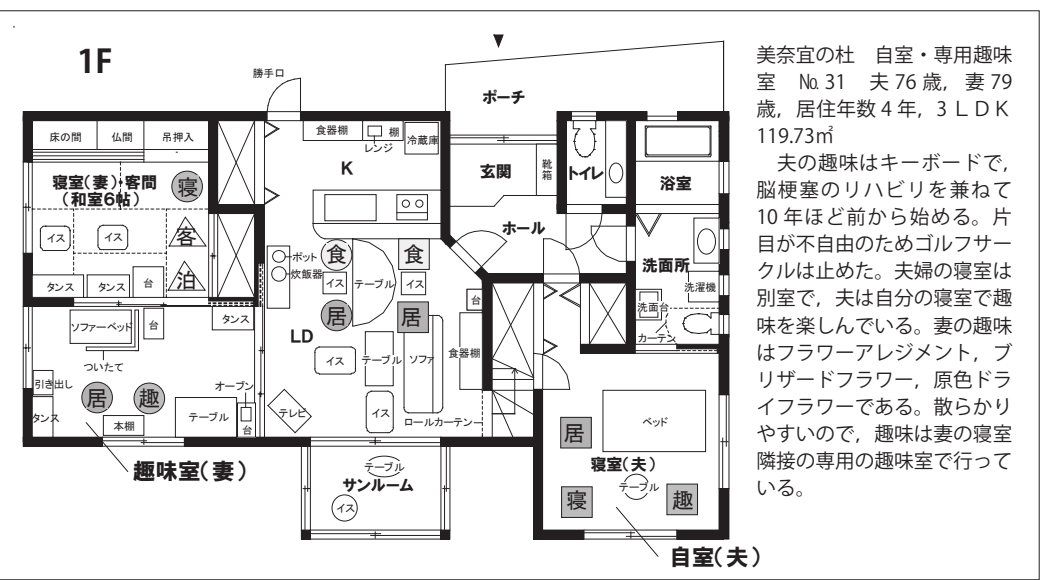

図 2 趣味空間 住まい方事例（美奈宜の杜 NO.31）

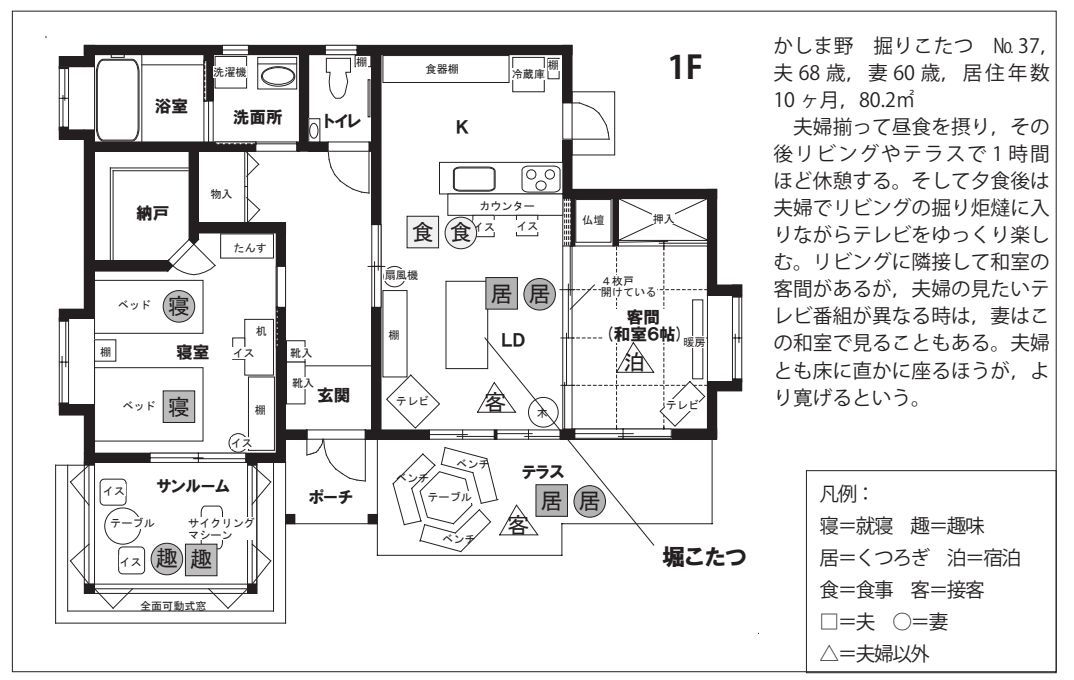

図 3 くつろぎ空間 住まい方事例（かしま野 NO.37）

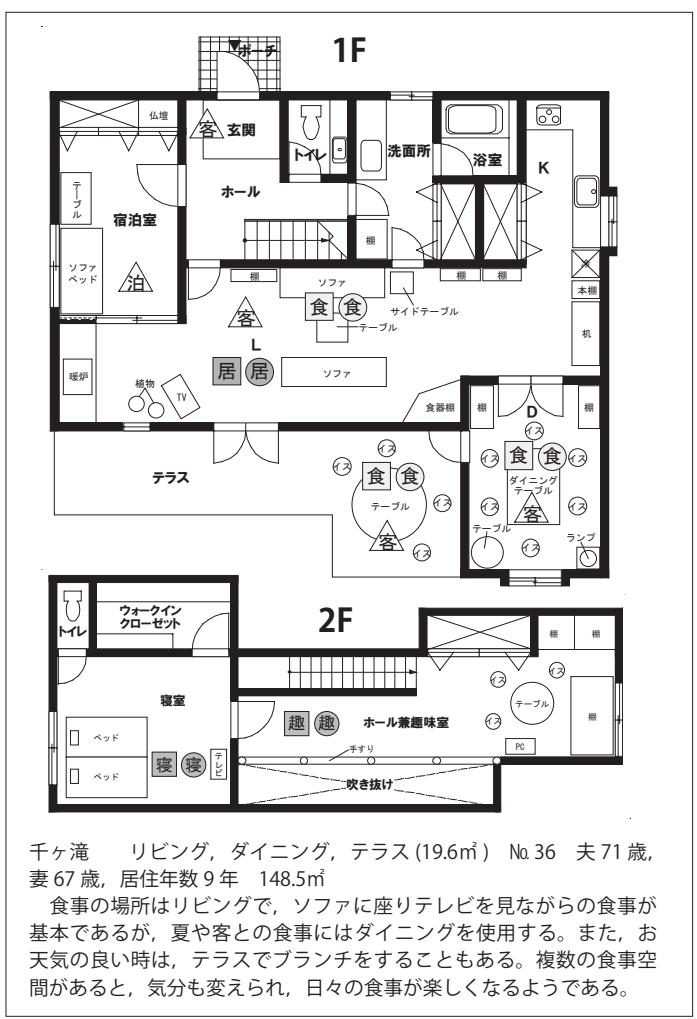

図４食事空間＼cjkstart住まい方事例（千ヶ滝 NO.36）

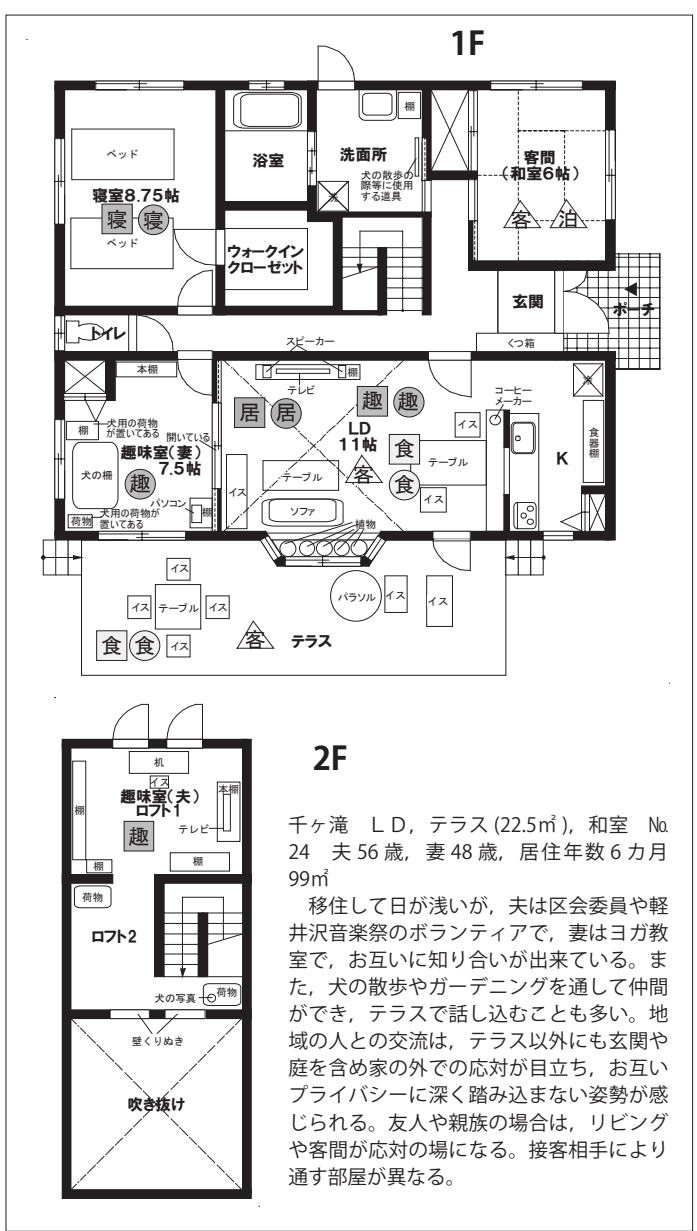

図 5 接客空間 住まい方事例（千ヶ滝 NO.24） 
以上, 空間からみた住まい方をまとめると, 生活の拠点は広い LDK で, 就寝以外の食事・くつろぎ・接客・趣味の行為が行われて いることがわかる(図 6)。ちなみに，食事は D コーナー, くつろぎ と接客は L コーナー, 趣味は夫が L コーナー, 妻が D コーナーと, 各行為は分節しているが，オープンな LDK で連携している。LDK 以外には，客間が遠来の客をもてなすために宿泊室とともに確保さ れ，さまざまなタイプの趣味空間が自己実現を図るために設けられ ている。さらに，LD に接する広いテラスでは，ブランチやバーベ キュー, 喫茶などの飲食, 庭を眺めながらの休息, 隣人との気軽な 接客, そして読書などの趣味が行われている。テラスはアウトドアリ ビングの役割を果たしており，LD と庭の仲介役になっている。

なお，移住当初から夫婦二人の生活に限定されるため，空間の使 われ方に関してはシルバーステージによる差異は認められなかった。 3-2 プランタイプ別にみた住まい方

LDK 以外の居室数によって, 住まい方がどのように異なるかを分 析する。まず，1LDK〜4LDK のタイプ別住まい方をみる（図 7)。 $1 \mathrm{LDK}$ （LDK 以外 1 室）は寝室のみ，2LDK は寝室と客間の組み合 わせが大半を占める。3LDK では, 趣味室の確保や夫婦別寝室にな る, 客間が接待と宿泊用の 2 室になるなど, バリエーションが生ま れる。4LDK になると, 夫婦それぞれの趣味室や夫婦別の寝室, あ るいは客間が 2 室用意される。地域により傾向が異なり，千ヶ滝は 客間が 2 室の割合が高く (13 戸・35.1\%)，美奈宜の杜は寝室が 2 室の割合が高い（16戸・34.8\%）が, 全体としては, 居室数が増え ると趣味室の割合が高くなる（図 8)。

以上, プランタイプ別にみた住まい方は, 寝室, 客間, 趣味室の 空間の有様は居室数によって異なり, 寝室以外まず客間が確保され, つぎに趣味室，最後に 2 つ目の寝室になることがわかる。

\section{4. 時間と生活との関係からみる居住スタイル}

本章では生活時間から住まい方をみていく。分析対象は有効回 答が得られた千ヶ滝 21 戸, かしま野 20 戸, 美奈宜の杜 32 戸の計 73 戸である。

\section{4-1＼cjkstart時間からみた住まい方}

生活内容を, 睡眠, 食事, 家事, くつろぎ, 趣味の 5 つに大別し, それぞれの行為を，一日で行う時間帯や時間量から，夫婦別に把握 する注 9) (表 7)。

\section{1) 睡眠時間}

睡眠は，人間にとって健康を維持するために不可欠な行為で，す べての人が 1 日のほぼ 3 分の 1 を費やす行為である。睡眠時間の平 均は, 夫で 8.1 時間, 妻で 8.0 時間, 若干妻のほうが短い。少ない 人で 6 時間, 多い人で 10 時間である。起床時刻は, 平均 6 時, 就 寝時刻は平均 22 時である。どちらかというと, 夫は早寝遅起, 妻 は遅寝早起の傾向がある。

\section{2）食事時間}

3 度の食事は，定刻に夫婦一緒に摂るのが一般的で，食事時間 で一日の生活リズムが構築されるといえる。朝食時刻は, 平均 7 時, 食事時間は 30 分から 60 分である。昼食時刻は 12 時〜 13 時, 食事時間は 30 分から 60 分の間である。夕食は 18 時または 19 時 から始め, 晚酌をしながら 60 分から 90 分かけてゆっくり食べる。 夕食は夫婦団らんの時間と考えている人が多い。1 日のうち食事に

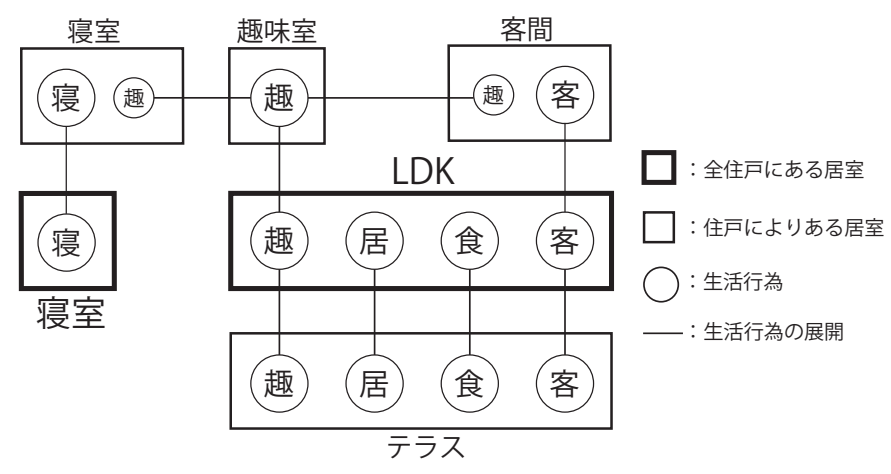

図 6 空間からみた住まい方（生活空間の展開）

\begin{tabular}{|c|c|c|c|}
\hline $\begin{array}{l}\text { 1LDK } \\
\text { (5戸) }\end{array}$ & $\begin{array}{l}\text { 2LDK } \\
(43 \bar{F})\end{array}$ & $\begin{array}{l}\text { 3LDK } \\
\text { (39戸) }\end{array}$ & $\begin{array}{l}\text { 4LDK } \\
(23 \bar{F})\end{array}$ \\
\hline \multirow{3}{*}{ 寝 } & & $\begin{array}{l}\text { 寝 } \cdot \text { 寝 } \cdot \text { 客 } \\
\quad(21.6 \%)\end{array}$ & $\begin{array}{c}\text { - 寝 } \cdot \text { 寝 } \cdot \text { 客 - 趣 } \\
(22.7 \%)\end{array}$ \\
\hline & $\begin{array}{l}\text { 寝・客 } \\
(75.6 \%)\end{array}$ & $\begin{array}{c}\text { 寝·客·起 } \\
\quad(40.5 \%)\end{array}$ & $\begin{array}{c}\text { 寝 - 客 · 趣 - 趣 } \\
(27.3 \%)\end{array}$ \\
\hline & & $\begin{array}{l}\text { 寝·客·容 } \\
\quad(21.6 \%)\end{array}$ & $\begin{array}{c}\text { - 寝 · 客 · 客 - 趣 } \\
(18.2 \%)\end{array}$ \\
\hline
\end{tabular}

図 7 プランタイプ別にみた住まい方

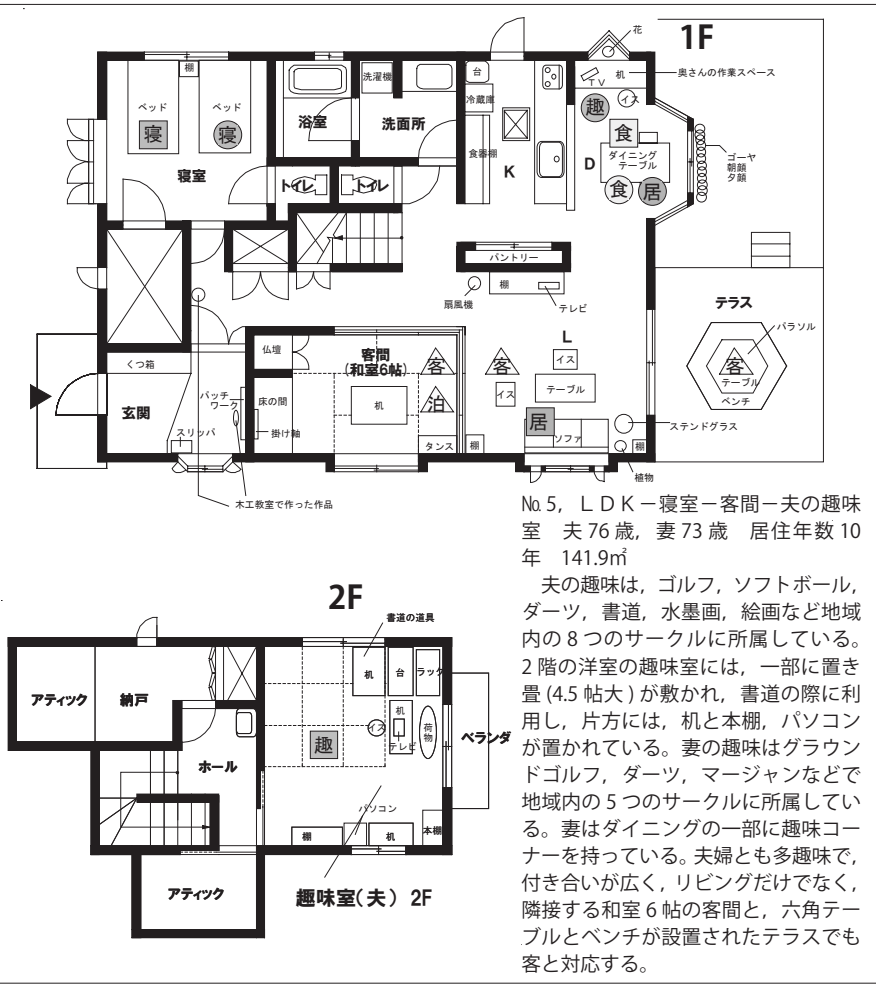

図 8 3LDK 住まい方事例（美奈宜の杜 NO.5）

かける時間量は, 簡単な準備や後片付け, 食後の食卓での会話を 含めると, 夫 2.8 時間, 妻 2.9 時間である。意外と食事に関わる 時間は多い（図 9)。

\section{3) 家事時間}

日常生活を快適にする基幹的家事として調理・洗濯・掃除を取り 上げ，それに日常的な買物も加える。家事に費やす平均的時間は， 夫で 1 時間, 妻で 3.2 時間である。全般的に家事は妻中心で行われ ており, とくに調理や洗濯は妻のみという住戸が多いが, ゴミ出し, 
表 7 地域別の生活時間配分（夫/妻）

\begin{tabular}{|c|c|c|c|c|c|c|}
\hline & \multirow{2}{*}{$\begin{array}{c}\text { 人数 } \\
\text { (計73) }\end{array}$} & \multicolumn{5}{|c|}{ 夫 } \\
\cline { 3 - 7 } & - & 睡眠 & 食事 & 家事 & くつろぎ & 趣味 \\
\hline 平均 & - & $\mathbf{8 . 1}$ 時間 & $\mathbf{2 . 8}$ 時間 & 1.0時間 & $\mathbf{4 . 4}$ 時間 & $\mathbf{5 . 2}$ 時間 \\
\hline 千ヶ潼 & 21 & 8.0 & 2.9 & 0.9 & 4.6 & 5.2 \\
\hline かしま野 & 20 & 8.1 & 2.8 & 0.9 & 4.3 & 5.3 \\
\hline 美奈宜の杜 & 32 & 8.2 & 2.8 & 1.3 & 4.2 & 5.0 \\
\hline
\end{tabular}

\begin{tabular}{|c|c|c|c|c|c|c|}
\hline & \multirow{2}{*}{$\begin{array}{c}\text { 人数 } \\
\text { (計73) }\end{array}$} & \multicolumn{5}{|c|}{ 妻 } \\
\cline { 3 - 7 } & - & $\mathbf{8 . 0}$ 眠 & 食事 & 家事 & くつろぎ & 趣味 \\
\hline 平均 & $\mathbf{2 . 9}$ 時間 & 3.2 時間 & $\mathbf{3 . 4}$ 時間 & $\mathbf{4 . 2}$ 時間 \\
\hline 千ヶ潼 & 21 & 8.0 & 3.0 & 3.2 & 3.3 & 4.2 \\
\hline かしま野 & 20 & 7.8 & 2.9 & 3.2 & 3.3 & 4.3 \\
\hline 美奈宜の杜 & 32 & 8.1 & 2.8 & 3.1 & 3.5 & 4.2 \\
\hline
\end{tabular}

風呂掃除，庭の手入れなどは夫中心で行われている住戸も比較的目 立つ(詳細は後述)。家事時間に夫婦間の差があるものの，これま で全く家事を分担していなかった夫が退職後，あるいは移住後に家 事をするようになり, 家事の負担量が軽減されたと感じる妻は多い。 家事の時間帯は, 調理以外は主に午前中に妻が掃除・洗濯を済ませ る傾向が見られる注10) (図 10)。

4) くつろぎ時間

心を解放してゆったり静かに過ごす, くつろぎは受動的な活動で, その内容としては, テレビ・ラジオや新聞・雑誌, 談話, また㡺寝・ ごろ寝などがあげられる。1 日におけるくつろぎの時間量は，夫平 均 4.4 時間, 妻平均 3.4 時間で妻が少ない。そのうちテレビの視聴 時間は, 夫婦とも $1 \sim 3$ 時間が多い。くつろぎの内容として, 新聞 は朝と午前に読む傾向がみられ, テレビは主に午後と夜に視聴され, 特に夜は夫婦一緒のことが多い。

5) 趣味時間

趣味を持つことは，高齢期の生活の中での大きな楽しみのひとつ であり, 喜びや生きがいにつながる。趣味に費やす時間は, 夫で 5.2 時間, 妻で 4.2 時間が平均である。夫は午前中から自宅あるいは自 宅外で趣味に従事する傾向にある。午後からは, 夫も妻も各々の趣 味に従事する（図 11）。
以上，時間からみた住まい方をまとめると，夫婦二人の生活は「睡 眠」「食事」以外の「家事」「趣味」「くつろぎ」の 3 つの行為の配 分で決定される傾向にある (図 12)。夫と妻で生活時間配分が異な る。夫の生活は「家事」が少なく「趣味」と「くつろぎ」に二分し, 妻の生活は「家事」と「趣味」と「くつろぎ」に三分される。夫は個 の時間 (趣味とくつろぎ) が 9.6 時間と長いが，共の時間（食事と 家事）は 3.8 時間と少ない。妻は個の時間が 7.6 時間，共の時間も 6.1 時間で，両者はそれほど差がない。

\section{4-2 シルバーステージ別にみた生活時間の配分}

前述の行為の睡眠, 食事, 家事, 〈つろぎ, 趣味の生活時間の配 分は年齢を重ねるごとにどのように変化しているのかをみる。～～ 5 段階のシルバーステージ別の住まい方を夫婦別に分析する（表 8)。

stage0（60 歳未満）では, 趣味に費やす時間が夫婦とも他のス テージに比べ長い。stage1（60 歳〜 64 歳）では, 夫婦とも睡眠 時間が他の stage よりも短く, 家事時間が他の stage よりも長い。 stage2 (65 歳〜 69 歳) では, 夫の睡眠時間が 7.8 時間で短い。 stage3（70 歳〜 74 歳）では, くつろぎと趣味の時間の差が縮まる 傾向にある。stage4 (75 歳〜 79 歳) になると, 夫婦とも趣味より もくつろぎ時間が長くなる。 stage5（80 歳以上）になると, 夫の睡 眠時間は 8.8 時間と長くなる。家事に費やす時間は, 夫婦とも短く
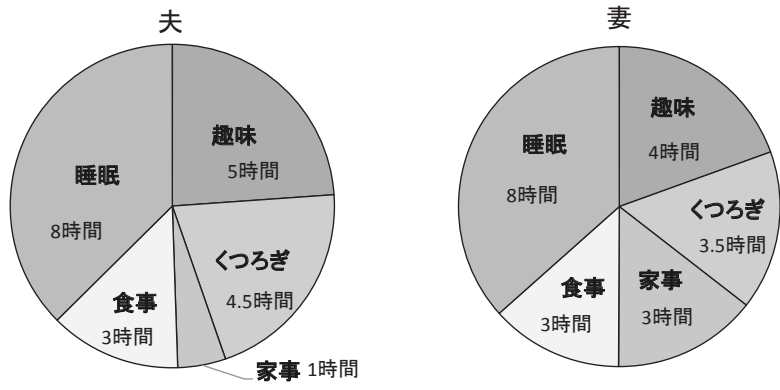

図 12 1 日の生活時間の配分（夫/妻）

\begin{tabular}{|c|c|c|c|c|c|c|c|c|c|c|c|c|c|c|}
\hline \multicolumn{2}{|c|}{ 時間帯 } & 3 & \begin{tabular}{l|l}
4 & 5 \\
\end{tabular} & 6 & 7 & 8 & 9 & \begin{tabular}{l|l}
10 & 1 \\
\end{tabular} & 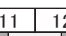 & \begin{tabular}{l|l}
2 & 13 \\
\end{tabular} $\mathrm{ar}$ & \begin{tabular}{l|l|l|l|l}
14 & 15 & 16 & 17 & 18 \\
\end{tabular} & 19 & \begin{tabular}{l|l|}
21 & 22 \\
\end{tabular} & \begin{tabular}{l|l}
23 & 0 \\
\end{tabular} \\
\hline \multirow{2}{*}{ 夫 } & 行動 & & 睡眠 & 新聞 & 食事 & \begin{tabular}{|l} 
ゴミ \\
出
\end{tabular} & & 手入れ & 食事 & ゴルフ & 読書·デッサン·DIY & \multicolumn{3}{|c|}{ 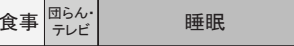 } \\
\hline & 場所 & & 寝室 & & - & 集栍所 & & 庭 & L & 練習所 & 別棟 (夫趣味室) & L & \multicolumn{2}{|c|}{ 寝室 } \\
\hline \multirow{2}{*}{ 妻 } & 行動 & & 睡眠 & & 食事 & 新聞 & 洗濯 & 刺紼 & 食事 & & ツチワーク・ビーズ手芸 & 食事 & 団らん·テレビ & 睡眠 \\
\hline & 場所 & & 寝室 & & & L & $\begin{array}{l}\text { 洗面 } \\
\text { 所 }\end{array}$ & 别棟(妻 & L & & 別棟(妻趣味室) & & L & 寝室 \\
\hline
\end{tabular}

図 9 食事時間 生活時間事例（かしま野 NO.7 宅）
N No.7, 夫 71 歳, 妻 70 歳居住年数 1 年, $62.7 \mathrm{~m}^{2}$ 夫婦とも多趣味で，それぞれ別棟で，お互い趣 味三昧の生活を送っている。しかし，3度の食事 は，定刻（朝食は 7 時〜 8 時，昼食は 12 時〜 13 時, 夕食は 19 時〜 20 時）に母屋のダイニングで夫婦 一緒に摂る。食事時間は唯一の夫婦団らんのひと ときであり，食事時刻で 1 日の生活リズムを作つ ている。

\begin{tabular}{|c|c|c|c|c|c|c|c|c|c|c|c|c|c|c|c|c|c|}
\hline \multicolumn{2}{|c|}{ 時間帯 } & \begin{tabular}{l|l}
3 & 4 \\
\end{tabular} & 5 & 5 & 6 & \begin{tabular}{|l|l|l|}
7 & 8 \\
\end{tabular} & 9 & \begin{tabular}{l|l}
10 & \\
\end{tabular} & 11 & & 13 & \begin{tabular}{l|l}
14 & 15 \\
\end{tabular} & 16 & 17 & \multicolumn{3}{|c|}{\begin{tabular}{|l|l|l|l|l|l|l}
18 & 19 & 20 & 21 & 22 & 23 & 0 \\
\end{tabular}} \\
\hline \multirow{2}{*}{ 夫 } & 行動 & 睡眠 & $\begin{array}{l}\text { 新 } \\
\text { 聞 }\end{array}$ & 散歩 & 烋息 & 苓| & 手休息 & 買物 & $\begin{array}{l}\text { 休 } \\
\text { 息 }\end{array}$ & & 休息 & パソコン & 休息 & \begin{tabular}{|l|} 
食事 \\
\end{tabular} & テレビ & 休息 & 睡眠 \\
\hline & 場所 & 寝室 & L & 外 & L D & L·庭 & L & 店 & L L & D & L & 夫趣味室 & L & D & \multicolumn{2}{|c|}{ L } & 寝室 \\
\hline \multirow{2}{*}{ 妻 } & 行動 & 睡眠 & $\begin{array}{l}\text { 気 } \\
\text { 功 }\end{array}$ & 散歩 & $\begin{array}{l}\text { 家自 } \\
\text { 事 }\end{array}$ & 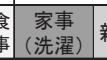 & 新聞 & 買物 & 家事直 & & 休息 & 編み物 & 休家 & 食事 & テレビ & 休息 & 睡眠 \\
\hline & 場所 & 寝室 & \begin{tabular}{|l|l|} 
寝 \\
\end{tabular} & 外 & $\mathrm{K} \mid \mathrm{D}$ & $\begin{array}{l}\text { 水趈り } \\
\text { 二ラス }\end{array}$ & L & 店 & $\mathrm{k}$ & & L & 妻趣味室 & L $\mathrm{K}$ & D & \multicolumn{2}{|c|}{ L } & 寝室 \\
\hline
\end{tabular}

図 10 家事時間 生活時間事例（美奈宜の杜 NO.21 宅）
(时)

№. 21，夫 62 歳，妻 61 歳 居住年数 2 年 $116.6 \mathrm{~m}$ 調理は妻が全て行うが，掃除は妻が苦手なため主 に夫がするという。庭の手入れ (芝刚り・草取り) も夫の担当である。午前中の早い時間帯に家事を済 ませ，一緒に買い物に行くというのが生活のパター ンとなっている。午後は、それぞれの趣味を行うが, 趣味時間以外は殆ど夫婦一緒に過ごしている。家事 分担を上手にしてお互い気持よく生活しているのが 伝わってくる。

\begin{tabular}{|c|c|c|c|c|c|c|c|c|c|c|c|c|c|c|c|c|c|c|c|c|}
\hline \multicolumn{2}{|c|}{ 時間帯 } & 3 & 4 & 5 & 6 & & 7 & \begin{tabular}{l|l}
8 & 9 \\
\end{tabular} & 10 & 11 & 12 & 13 & 15 & 16 & 17 & 18 & \begin{tabular}{l|l}
19 & 20 \\
\end{tabular} & 21 & \begin{tabular}{|c|}
22 \\
読書 \\
\end{tabular} & 0 \\
\hline \multirow{2}{*}{ 夫 } & 行動 & \multicolumn{3}{|c|}{ 睡眠 } & $\begin{array}{l}\text { 新 } \\
\text { 聞 } \\
\end{array}$ & & 掃除 & $\begin{array}{c}\begin{array}{c}\text { テレビ·新 } \\
\text { 聞 }\end{array} \\
\end{array}$ & \multicolumn{2}{|c|}{ トレーニング } & \multicolumn{2}{|c|}{ 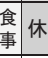 } & 陶芸 & 買物 & 休息 & 食事 & $\begin{array}{c}\text { テレビ } \\
\text { 新聞 }\end{array}$ & \multicolumn{2}{|r|}{ 読書 } & 睡眠 \\
\hline & 場所 & & 寝室 & & L & & & L & トレー & $\begin{array}{l}\text {-ニングジ } \\
\text { ム }\end{array}$ & $\mathrm{D}$ & L & 陶芸教室 & 店 & L & D & L & \multicolumn{2}{|c|}{ 夫趣味室 } & 寝室 \\
\hline \multirow{2}{*}{ 妻 } & 行動 & & 睡眠 & & 調 & 食 & 洗濯 & \multicolumn{2}{|c|}{ ガーデニング } & \begin{tabular}{|l|l|l} 
パン & 調 \\
作り & 理 \\
\end{tabular} & 周金食 & 休息 & 陶芸 & 買物 & 調理 & 食事 & $\begin{array}{c}\text { テレビ } \\
\text { 新聞 }\end{array}$ & \begin{tabular}{|l|} 
ピアノ \\
練習
\end{tabular} & \begin{tabular}{|c}
$\begin{array}{c}\text { 休息·テレ } \\
\text { ビ }\end{array}$ \\
\end{tabular} & 睡眠 \\
\hline & 場所 & & 寝室 & & $\mathrm{K}$ & D & 面 & \multicolumn{2}{|l|}{ 庭 } & $\mathrm{K}$ & D & L & 陶芸教室 & 店 & $\mathrm{K}$ & D & & 寝室 \\
\hline
\end{tabular}

(時)

№. 17, 夫 64 歳，妻 59 歳，居住年数 3 年 $198.0 \mathrm{~m}^{2}$ 夫婦共通の趣味は陶芸で，2 人で陶芸教室に習い に行く。また，夫はトレーニングジムに週 1，2 回通つ ている。妻は，ピアノを習い始め，その他にもテ二 スやガーデーングという趣味を持っている。 一緒に摂るが，〈つろぐ時は，夫は 2 階にある自分 の趣味室で，妻はリビングでというようにそれぞれ 好きに過ですという。何か一つでも共通の趣味を持

図 11 趣味時間 生活時間事例（千ヶ滝 NO.17 宅） つことはいい夫婦関係を保つためには大切である。 
表 8 シルバーステージ別の生活時間配分（夫／妻）

\begin{tabular}{|c|c|c|c|c|c|c|}
\hline & \multirow{2}{*}{$\begin{array}{c}\text { 人数 } \\
\text { (計73) }\end{array}$} & \multicolumn{5}{|c|}{ 夫 } \\
\cline { 3 - 7 } & - & 睡眠 & 食事 & 家事 & くつろぎ & 趣味 \\
\hline 平均 & - & $\mathbf{8 . 1}$ 時間 & 2.8 時間 & 1.0時間 & $\mathbf{4 . 4}$ 時間 & 5.2 時間 \\
\hline stage0 & 5 & 7.7 & 2.6 & 1.5 & 3.8 & 5.8 \\
\hline stage1 & 15 & 7.7 & 2.7 & 1.5 & 4.1 & 5.5 \\
\hline stage2 & 26 & 7.8 & 2.8 & 1.2 & 4.2 & 5.5 \\
\hline stage3 & 18 & 8.0 & 3.0 & 1.0 & 4.4 & 5.0 \\
\hline stage4 & 5 & 8.3 & 3.0 & 0.8 & 5.2 & 4.4 \\
\hline stage5 & 4 & 8.8 & 3.1 & 0.4 & 5.5 & 3.8 \\
\hline
\end{tabular}

\begin{tabular}{|c|c|c|c|c|c|c|}
\hline & \multirow{2}{*}{$\begin{array}{c}\text { 人数 } \\
\text { (計73) }\end{array}$} & \multicolumn{5}{|c|}{ 妻 } \\
\cline { 3 - 7 } & - & 睡眠 & 食事 & 家事 & くつろぎ & 趣味 \\
\hline 平均 & - & $\mathbf{8 . 0}$ 時間 & $\mathbf{2 . 9}$ 時間 & 3.2 時間 & $\mathbf{3 . 4}$ 時間 & 4.2時間 \\
\hline stage0 & 13 & 7.9 & 2.7 & 3.0 & 3.3 & 4.6 \\
\hline stage1 & 23 & 7.8 & 2.8 & 3.4 & 3.1 & 4.5 \\
\hline stage2 & 24 & 7.9 & 3.1 & 3.3 & 3.1 & 4.2 \\
\hline stage3 & 9 & 8.1 & 3.0 & 3.0 & 3.5 & 4.0 \\
\hline stage4 & 3 & 8.2 & 3.2 & 2.6 & 3.9 & 3.7 \\
\hline stage5 & 1 & 8.3 & 3.4 & 2.4 & 4.0 & 3.5 \\
\hline
\end{tabular}

表 9 シルバーステージ別の生活時間配分（夫十妻）

\begin{tabular}{|c|c|c|c|c|c|c|}
\hline 夫+妻 & 146 & 睡眠 & 食事 & 家事 & くつぎ & 趣味 \\
\hline 平均 & - & $\mathbf{8 . 1}$ 時間 & 3.0時間 & 2.0 時間 & 4.1 時間 & 4.5 時間 \\
\hline stage0 2 & 106 & 7.8 & 2.8 & 2.3 & 3.6 & 5.0 \\
\hline stage3 & 27 & 8.1 & 3.0 & 2.0 & 4.0 & 4.5 \\
\hline stage4 5 & 13 & 8.5 & 3.2 & 1.6 & 4.7 & 3.9 \\
\hline
\end{tabular}

なる(図 13)。

以上，シルバーステージから高齢夫婦の生活時間をみると，行為 の時間量による年齢差が夫の方が妻に比べ大きい。年齢を重ねると 睡眠時間が長くなる分, 家事時間が短くなり，〈つろぎと趣味の時 間量が逆転する (表 9)。60 歳代, $70-74$ 歳代, 75 歳以上の順 に生活が変相する。stage $0 \sim 2$ は体力, 気力充分で趣味に夢中に なり, stage 3になると体力低下により趣味も徐々に整理し, 生活が 変わり始める。stage $4 \sim 5$ になると気力低下も起こり, 能動的な 趣味（体力を消耗するスポーツや仲間と行うサークル活動）は減り， 受動的な行為（読書，パソコン，音楽鑑賞など自宅で 1 人行う趣味） が増えて，のんびり過ごすようになる。

\section{4-3 空間と時間からみた自立高齢期の生活領域}

さまざまな束縛から解放されて自己に対峙することから，新しい 生活を組み立てていく高龄期の生活には,「個の自立」が根幹をなす。 自立に向けて，自己実現の成就が重要であるが，自己は他者との関 係で規定される注11。個の自立を果たすことは，自分自身の生活を コントロールすることであり,それが他者との関わりも自らコントロー ルすることにつながる。個人のプライバシーの確立は，他者とのコ ミュニケーションのための基盤となる。

空間と時間からみた夫婦の生活行為を，プライバシー(個人の自 立）とコミュニケーション（夫婦共生十他者との交流）の領域から 考察する (図 14)。高齢夫婦の生活時間は, 表 9 に示すと抢りで, 1 日 24 時間のうち睡眠を除く 16 時間のうち 5 割強の 8.6 時間が趣 味とくつろぎの「個人の自立」に費やされる。また 3 割の 5 時間が
食事と家事の「夫婦の共生」に使われる。趣味のなかでも仲間と行 うものがあり, 接客空間でみた来客頻度, ならびにその 2 で明らか にした地域での交流傾向からもわかるように,「他者との交流」は積 極的に行われている。生活領域としてのプライバシー二「個人の自立」 とコミュニケーション＝「夫婦共生」や「他者との交流」の割合はバ ランスがとれているといえる。このように調和がとれた安定した生活 を, ここではハーモナイズライフと称する。自立期にハーモナイズラ イフを送る高齢者は, その後の生活環境が変化しても, 居住継続の 可能性が高い。というのは，ヒアリング調查により 注 122，単身者は 配偶者の死後も自立した生活を送っている，要支援者は交流のある 地域住民に支援されている事例の多くから推測できる。さらに，「永 住断念層」は自立できなくて依存傾向が強く不満が大きい高齢者, あるいは地域住民との交流がなく孤立している高齢者である傾向が 強い。

\section{5. 夫婦関係と生活形態からみる居住スタイル}

本章では, 日常生活に扔ける夫婦の行動を把握し,「自立」「依 存」の視点で夫婦関係のパターンを導き出す。対象は，夫婦の居住 スタイルが把握できた夫婦のみ世帯, 千ヶ滝 29 戸, かしま野26戸, 美奈宜の杜 46 戸の計 101 戸である。

5-1日常生活からみた夫婦関係

1) 生活ルール

生活するうえでの夫婦間のルールの有無に関しては, 全体では「あ る」が 56 戸 $(55.4 \%)$ で半数をやや上回る。具体的な内容としては, 「できることは自分でする」(39.6\%), 「家事を分担する」(32.7\%), 「食事は必ず一緒に食べる」（30.7％）などがあげられる（図 15)。 複数のルールを持つ住戸が多く，ある部分は自立しながら，ある部 分は協力し合う, バランスのとれた取り決めをしている場合が多い。 なお，シルバーステージでタると, stage 0 や stage1 でルールがな い住戸が比較的多い。とくにまだ現役で働いているとその傾向がみ

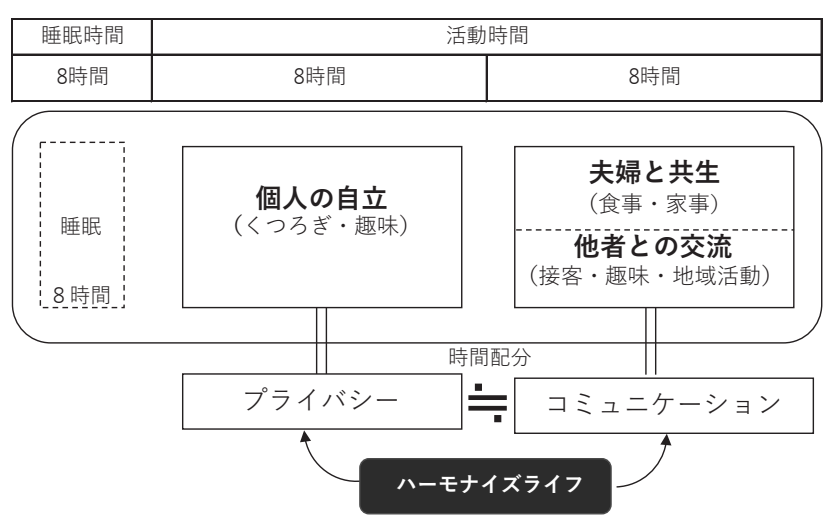

図 14 ハーモナイズライフの構図

\begin{tabular}{|c|c|c|c|c|c|c|c|c|c|c|c|c|c|}
\hline \multicolumn{2}{|c|}{ 時間带 } & \begin{tabular}{l|l|l|}
3 & 4 & 5 \\
\end{tabular} & \begin{tabular}{l|l}
6 & 6 \\
\end{tabular} & $7 \quad$ & \begin{tabular}{l|l}
3 & 9 \\
\end{tabular} & 10 & 11 & \begin{tabular}{|l|}
12 \\
\end{tabular} & \begin{tabular}{|l|l|l|l}
13 & 14 & 15 & 1
\end{tabular} & 17 & \begin{tabular}{l|l}
18 & \\
\end{tabular} & \begin{tabular}{|l|l|l|}
9 & 20 & 21 \\
\end{tabular} & \begin{tabular}{l|l|l}
22 & 23 & 0 \\
\end{tabular} \\
\hline 夫 & 行動 & 睡眠 & 新聞 & 食事 & 読書 & 買物 & 昼寝 & 食事 & 読書 & & 食事 & 団らん·テレビ & 睡眠 \\
\hline 82 & 場所 & 葠室 & L & D & L & 店 & $\begin{array}{l}\text { 夫趣 } \\
\text { 味室 }\end{array}$ & D & 夫趣味室·L & & D & L & 寝室 \\
\hline 妻 & 行動 & 睡眠 & & 食事 & 新公聞 & 買物 & 休調 & 食事 & パッチワーク & 調理 & 食事 $\left.\right|_{\text {片 }}$ & 団らん・テレヒ & 睡眠 \\
\hline 79 & 場所 & 寝室 & K & D & $\mathrm{L}$ & 店 & \begin{tabular}{ll|l|l|} 
&
\end{tabular} & D & L & $\mathrm{k}$ & $\begin{array}{ll}D & K\end{array}$ & L & 寝室 \\
\hline
\end{tabular}

図 13 stage5 生活時間事例（かしま野 NO.27 宅）
(時)

NO. 27 夫 82 歳, 妻 79 歳 居住年数 3 年, $92.4 \mathrm{~m}^{2}$ 定年後, 16 年間アメリカで暮らした経験がある。 夫は 8 時間の睡眠では足りず，趣味室で㡺寝を執る。 夫の趣味は読書と野菜作りである。読書は 1 日 6 時 間を超え, リビングや夫の趣味室で行う。以前は夫婦 でゴルフをしていたが，体力面で数年前に辞めた。妻 の趣味はパッチワークとエアロビクスである。パッチ ワークはリビングの空際にあるミシンを使う。買物は 夫の運転で夫婦一緒に出掛ける。 


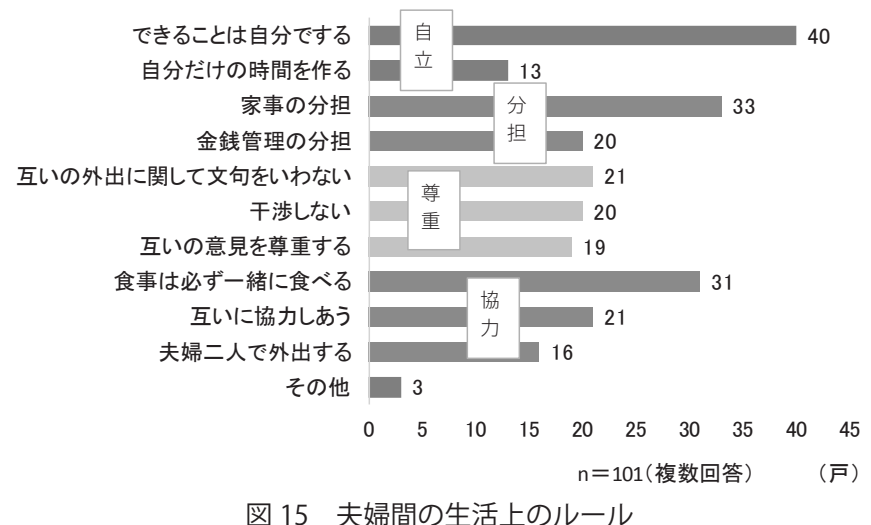

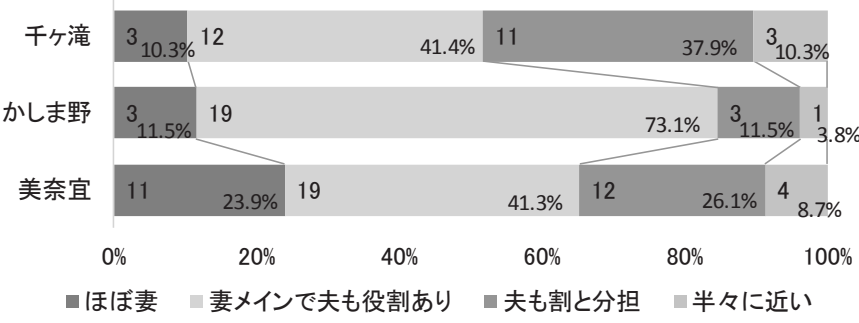

図 16 夫婦間の家事分担の割合

られる。

2) 家事分担

夫婦間の家事の担当・分担に関しては, 家事内容によって差異が みられた。妻のみが行うことが多い家事は,「洗濯」(71.3\%),「料理」 (62.4\%), 夫の夕が多いものは,「ゴミ出し」(41.6\%),「風呂掃除」 (21.8\%), 分担が多いものは「庭の手入れ」(68.3\%),「部屋の掃除」 (49.5\%),「食後の後片付け」(53.5\%) である。

家事の分担を総合的に判断し, 夫婦の分担割合を以下のように分 類した。夫の方が比重が高い住戸は皆無で, 夫の家事負担が低い 順に「ほとんど妻が行う」(16.8\%),「妻がメインに行うが, 夫も何 かしら役割を持っている」(49.5\%),「妻の方が多いが, 夫もかな り分担している」(25.7\%),「ほぼ半分ずつ分担している」（7.9\%) という結果であった（図 16）。また，シルバーステージが高いと妻の 家事負担の割合が高く, 居住年数が短いと分担する割合が高い。こ れは世代抢よび時代による固定観念の影響が強いと考えられる。多 くの住戸では, 夫が現役時代は妻がほぼ家事をしていたが, 退職に ともなって夫も徐々に家事をするようになっている。

3) 外出行動

対象地では車移動がメインとなるため, 運転免許の保有率は外出 行動を左右する。運転免許の保有率は, 夫が $89.1 \%$, 妻が $70.3 \%$ である。夫婦間での運転状況をみると, 夫婦どちらとも免許を持た ない住戸は 4 戸のみ（かしま野 1 戸，美奈宜の 杜 3 戸) で，二人とも頻繁に運転する住戸が 57 戸 (56.4\%), 夫のみ運転が 34 戸 $(33.7 \%)$, 妻のみ運転が 6 戸 (5.9\%) である。

誰と行動するかを外出先別にみると, 病院や 友人に会う時は一人で行動する場合と夫婦で行 動する場合とは打よそ半々で, これは運転の能 否が影響している。一方, 買い物や外食は夫婦
そろって行動する住戸が 8 割を超え多い。夫婦とも運転する場合で も, これらの行為は一緒に行うというのが特徵である。

4) 介護相手

将来介護が必要になったとき, 誰に介護してもらいたいか聞いた ところ 淓 ${ }^{13)}$, 夫・妻とも「配偶者」(73.3\%) と「専門職」(60.0\%) という回答が圧倒的で, それ以外の回答はごく少数である。「配偶 者に介護してほしい」という回答は, 妻より夫のほうが 1 割ほど上回 る。

\section{5）趣味活動からみた夫婦関係}

趣味の内容についてはその 2 で詳細に述べたが，ここでは夫婦単 位でみた趣味の内容やバランスについてみていく。

夫婦で共通の趣味を持っている住戸は 56 戸 (55.4\%) と半数強 であるが, 地域により差異がみられる。共通の趣味の内容はゴルフ がもっとも多く (20戸), 次いでガーデニング・畑 (10 戸), 散歩・ウォー

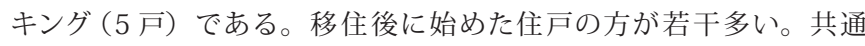
の趣味の数は 1 つが大半であるが, なかには 2 つ， 3 つという住戸 もある。相対的に, 趣味が多い住戸は夫婦とも複数の趣味を持ち, 少ない住戸は夫婦ともに少ないという傾向がある。これは近所づき あいにも同様のことがいえる主 14)

5-2 自立と依存からみた夫婦関係のパターン

上記にあげた「夫婦間のルール」「家事分担」「車の運転」「外出 行動」「介護相手」「趣味」「近所づきあい」はそれぞれ，その内容によっ て「自立的な行為 (・志向)」もしくは「依存的な行為」に振り分け ることができる。各住戸に揸いて，これらの行為・志向を総合的に 判断し，夫婦関係のタイプを分類すると，「協力自立」(49.5\%)，「独 立自立」 $(20.8 \%)$, 「夫婦とも依存」 $(13.9 \%)$, 「妻に依存」 $(8.9 \%)$, 「夫に依存」（6.9\%）の5つになる（表 10）。実に 7 割の住戸が自 立タイプに入る。

それぞれのタイプの特徵をまとめると以下のようになる（具体例を 表 11 に示す)。まず自立要素の強い「独立自立」と「協力自立」タ イプは，お互いを干渉せず，家事もそれなりに分担し，各自で趣味 など打ち込めるものを持っているところが共通点である。そのうち「独 立自立」は，夫婦で一緒に行動することは少なく，「協力自立」は 夫婦共通の趣味を持っていたり, 何かしら一緒に活動するものがあ る住戸が該当する。互いに自立できているので, 健康であることと, 趣味や近所づきあいを通して配偶者以外の人物とも積極的に交流で きていることが条件といえる。一方, 依存要素の強い「妻に依存」「夫 に依存」「共に依存」タイプは, 家事分担, 車の運転, 近所づきあ いなどのバランスが夫婦間で偏向しており，どちらかに何らかを依 存しながら生活している。また他者との関わりが少ないと, 必然的 に配偶者にかかる負担が大きくなってくる。いずれも高齢で身体状

表 10 自立と依存からみた夫婦関係のパターン

\begin{tabular}{|c|c|c|c|c|c|c|c|c|c|}
\hline & \multicolumn{7}{|c|}{ 夫婦間の行動·志向 } \\
\hline & & & ルール & 家事 & 運転 & 外出行動 & 介護相手 & 趣味 & 近所づきあい \\
\hline \multirow[b]{2}{*}{$\begin{array}{l}\text { 夫 } \\
\text { 婦 } \\
\text { 関 }\end{array}$} & 独立自立 & $\begin{array}{c}21 \text { 戸 } \\
(20.8 \%)\end{array}$ & 干渉しない & 夫婦で分担 & どちらも運転 & $\begin{array}{l}\text { 常にひとりで } \\
\text { 行動 }\end{array}$ & & $\begin{array}{l}\text { 共通の趣味 } \\
\text { なし }\end{array}$ & あり \\
\hline & 協力自立 & $\begin{array}{c}50 \text { 戸 } \\
(49.5 \%)\end{array}$ & $\begin{array}{l}\text { 協力する } \\
\text { 分担する }\end{array}$ & 夫婦で分担 & どちらも運転 & & & $\begin{array}{l}\text { 共通の趣味 } \\
\text { あり }\end{array}$ & あり \\
\hline 係 & \begin{tabular}{|c|} 
夫が妻に \\
依存
\end{tabular} & $\begin{array}{c}9 \bar{戸} \\
(8.9 \%) \\
\end{array}$ & 家事は妻 & $\begin{array}{l}\text { ほとんど妻が } \\
\text { 負担 }\end{array}$ & 妻のみ運転 & & $\begin{array}{l}\text { 夫は配偶者 } \\
\text { のみ希望 }\end{array}$ & & 妻のみあり \\
\hline \multirow{2}{*}{$\begin{array}{l}\text { タ } \\
1 \\
フ ゚\end{array}$} & \begin{tabular}{|c|} 
妻が夫に \\
依存
\end{tabular} & $\begin{array}{c}7 \text { 戸 } \\
(6.9 \%)\end{array}$ & & & 夫のみ運転 & & $\begin{array}{l}\text { 妻は配偶者 } \\
\text { のみ希望 }\end{array}$ & & 夫のみあり \\
\hline & \begin{tabular}{|c|} 
夫婦共に \\
依存
\end{tabular} & $\begin{array}{c}14 \text { 戸 } \\
(13.9 \%)\end{array}$ & & & & $\begin{array}{l}\text { 常に一ー緒に } \\
\text { 行動 }\end{array}$ & $\begin{array}{l}\text { 共に配偶者 } \\
\text { のみを希望 }\end{array}$ & $\begin{array}{l}\text { 共に趣味なし/ } \\
\text { 共通の帱味のみ } \\
\text { あり }\end{array}$ & あまりない \\
\hline
\end{tabular}


表 11 夫婦間の自立依存関係の具体例

\begin{tabular}{|c|c|c|c|c|}
\hline $\begin{array}{l}\text { 独立 } \\
\text { 自立 }\end{array}$ & $\begin{array}{l}\text { かしま野NO.4 } \\
\text { 夫(63)妻(64) } \\
\text { 居住年数1年 }\end{array}$ & 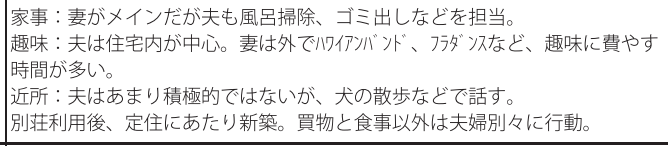 & $\begin{array}{l}\text { 千ヶ滝NO. } 47 \\
\text { 夫(64)妻(63) } \\
\text { 居住年数4年 }\end{array}$ & $\begin{array}{l}\text { 家事 : 夫は外回りの仕事を担当。風呂や部屋の掃除は夫婦で分担。 } \\
\text { 趣味 : 夫はゴルフ、スキ一、絵画、陶芸、妻は古い建物散策、裁縫、観光ボ } \\
\text { ランティアガイドなど、それぞれで活力。 } \\
\text { 近所 : 夫はクリスチャンで、近所にクリスチャン仲間がいる。 }\end{array}$ \\
\hline $\begin{array}{l}\text { 協力 } \\
\text { 自立 }\end{array}$ & $\begin{array}{c}\text { 美奈宜の杜NO.9 } \\
\text { 夫(70)妻(67) } \\
\text { 居住年数9年 }\end{array}$ & 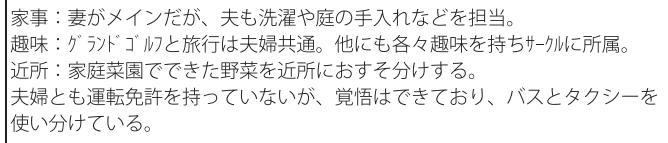 & $\begin{array}{l}\text { 千ヶ滰NO.31 } \\
\text { 夫(71)妻(69) } \\
\text { 居住年数11年 }\end{array}$ & $\begin{array}{l}\text { 家事：移住後に夫は風呂掃除などの家事を手伝うようになり、年々分担の割 } \\
\text { 合が増加。 } \\
\text { 趣味：ゴルフと音楽鑑賞は夫婦共通の趣味。 } \\
\text { 近所：ほかの移住者と環境が似ているので、気楽に付き合えている。夫婦単 } \\
\text { 位での交流がある。 }\end{array}$ \\
\hline $\begin{array}{l}\text { 夫が妻 } \\
\text { に依存 }\end{array}$ & $\begin{array}{l}\text { チヶ滝NO. } 26 \\
\text { 夫(67)妻(62) } \\
\text { 居住年数6年 }\end{array}$ & $\begin{array}{l}\text { 家事：夫は移住後家事を始め、現在はとても協力的。主に力仕事を担当。 } \\
\text { 趣味：共通の趣味はゴルつ。妻はパッチワーク教室を家で行う。夫は家で } \\
\text { ゲームや将棋。 } \\
\text { 近所：妻はつきあいは多いが、夫はほとんどない。 }\end{array}$ & $\begin{array}{c}\text { かしま野NO.9 } \\
\text { 夫(68)妻(62) } \\
\text { 居住年数13年 }\end{array}$ & $\begin{array}{l}\text { 家事 : ほぼ妻が行っている。 } \\
\text { 趣味 : 共通の趣味は麻雀。妻は巡回ケア訪問サーピスのボランテイをしている。 } \\
\text { 近所：趣味の麻雀を通して近隣の友人ができた。妻は人と関わることが好き } \\
\text { で、すぐに友だちができる。 }\end{array}$ \\
\hline $\begin{array}{l}\text { 妻が夫 } \\
\text { に依存 }\end{array}$ & \begin{tabular}{|c|} 
美奈宜の杜NO.4 \\
夫(76)妻(71) \\
居住年数9年
\end{tabular} & $\begin{array}{l}\text { 家事：ほとんど妻が行う。夫は風呂掃除と庭の手入れを担当。 } \\
\text { 趣味 : 夫は囲基、麻雀のサークルに所属 } \\
\text { 妻は水墨画のサークルつていたか、マンンリになってやめた。 } \\
\text { 近所：挨拶する程度で長話はしない。 }\end{array}$ & $\begin{array}{l}\text { チヶ滝N0.27 } \\
\text { 夫(67)妻(66) } \\
\text { 居住年数5年 }\end{array}$ & 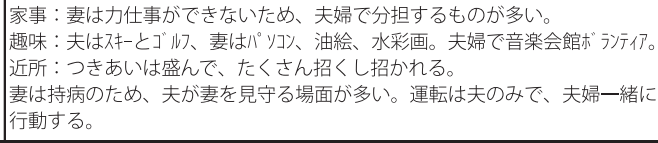 \\
\hline
\end{tabular}

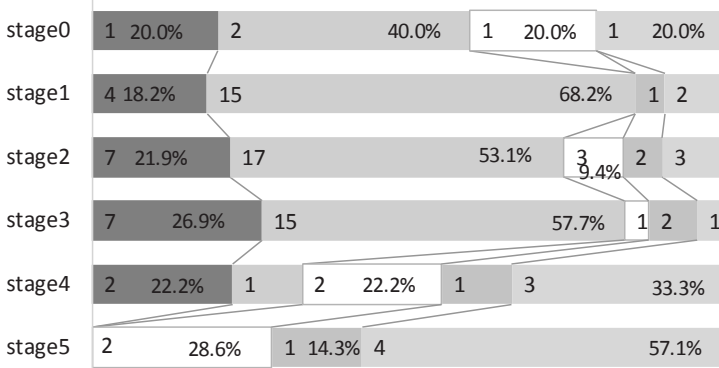

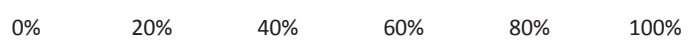

口独立自立協力自立口妻に依存

図 17 シルバーステージ別自立と依存からみた夫婦関係のパターン

況に不安を抱えている場合に多くみられる。なお,「妻に依存」は, まだ現役で働いている夫がいる住戸でも比較的みられるタイプであ る。

シルバーステージ別にみると, stage $1 \sim$ stage 3 は自立タイプが 8 割を占める一方, stage 0 と stage 4 〜 5 では依存タイプの割合が 比較的高い（図 17）。年齢が上昇すると, 身体状況の悪化, 趣味や 近所づきあいの減少により, 配偶者を頼る傾向があることが実態調 査から把握できた。とくに stage5 では「夫婦とも依存」の状態にな る割合が増すことが特徴といえる。

移住して新たに生活をスタートさせる高齢者にとっては，夫婦それ ぞれが自立した生活を送ることが肝要である。それには健康維持, それぞれが趣味や生きがいを持つこと, 趣味や近所づきあいを通し て他者との交流を持つことなどが重要なポイントとしてあげられる。 なかでも「自立協力」タイプは, 夫婦が “つかず離れず”の状態で, 良好な関係性といえる。

\section{6. まとめ}

本報により得られた自立高齢期夫婦の居住スタイルに関する知見 は以下のとおりである(図 18)。

(1) 高齢期の生活行為の居室展開をみると, 「就寝」と「趣味」の 一部以外の行為（「くつろぎ」「食事」「接客」）がすべて LDK に集 約されている。そして，テラスもアウトドアリビングとして活用されて
いる。LDK 以外の居室の用途としてまず寝室と客間(宿泊室を含む) を確保し, 居室数が増加すると, 趣味室または夫婦別寝室が確保さ れる。広いLDK に第 1 の自分の居場所を設け，夫婦がお互いに相 手を確認しながら過ごし，さらに第 2 の居場所として趣味空間を設 け，個の領域を確保して自己実現を図っている。

(2) 夫婦 2 人の生活行為の時間配分は,「睡眠」「食事」以外の「家 事」「趣味」「くつろぎ」の 3 つの行為が異なる。夫の生活は「家事」 が少なく「趣味」と「くつろぎ」に集中し, 妻の生活は「家事」と「趣 味」と「くつろぎ」に 3 等分される。食事で一日の生活リズムをつくり, 家事を分担しながら，それぞれが趣味やくつろぎで自立した生活を 送っている。夫婦とも個の時間（自立）を大切にしながらも，共の 時間 (共生) もそれなりに確保し, 夫婦生活のバランスを保っている。 (3) 高齢期の夫婦関係をみると，お互いを干渉せず，家事もそれな りに分担し, 各自で趣味など打ち込めるものを持っている「協力自立」 と「独立自立」が全体の 7 割を占める。年齢の上昇とともに依存要 素が強くなるが，もともと自立した生活や他者との交流を持っている ことにより, 過度の依存状態ではなく, 夫婦以外の他者との関係を 保ちながら変化に柔軟に対応できると考える。

(4) シンプル・コンパクト・オープンという特性を有する別荘は, 夫 婦のみの生活機能の単純性, 維持管理の利便性, 生活変化に対応 する可変性に適合する高齢期の生活に相応しい住宅といえる。広い

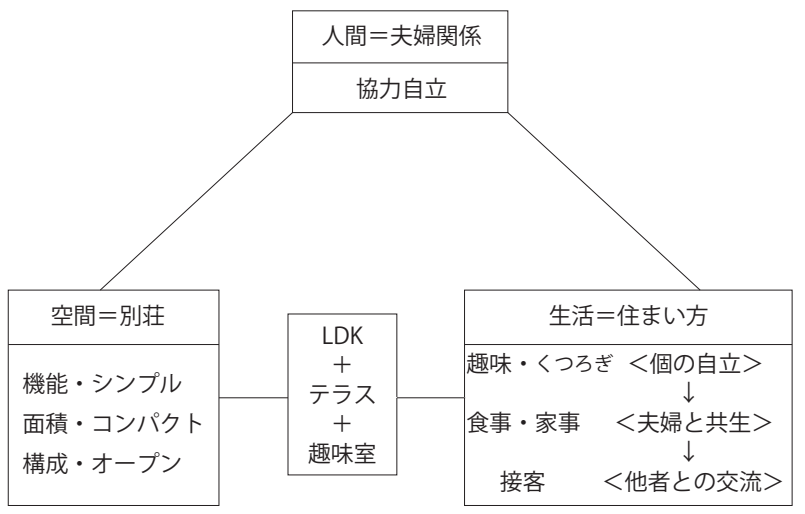

図 18 自立高齢期夫婦の居住スタイルの構図 


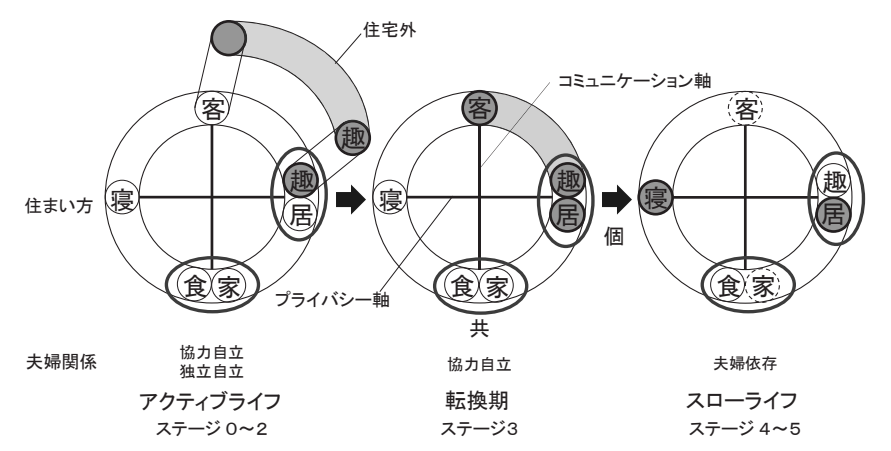

図 19 シルバーステージからみた自立高齢期夫婦の居住スタイルの変化

オープンな LD と，それに続く庭に接する広いテラスと，多様な趣

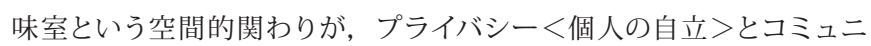
ケーションく夫婦の共生 $><$ 他者との交流 $>$ を軸とする生活領域を 両立させている。このような自立高齢期の安定した調和のとれた生 活, すなわち「ハーモナイズライフ」が, 個性的で地域とのつなが りがある活気あふれる高齢者像を生みだしている。

(5) 自立高齢期夫婦の居住スタイルを, シルバーステージごとにみ ると, 60 歳代, $70-74$ 歳代, 75 歳以上の順に生活が変相する (図 19)。 stage $0 \sim 2$ は, 体力, 気力充分で, 趣味を中心とした生活 が展開されるアクティブライフであるが, stage 3 になると, 体力低 下に伴い, 趣味の内容が変わり始め, 能動的なものから受動的なも のに変化する転換期となる。 stage 4 ～ 5 になると気力低下も起こり, 趣味が少なくなり, くつろぎが増える傾向にあり, スローライフにな る。 stage 3 は, コミュニケーションとプライバシーの生活を意識的 にコントロールする時期だといえる。また, stage 4 〜 5 になると接 客と家事が縮小し, コミュニケーション量が減少するが, 逆に見守り と支援が必要になる。オープンなプランとテラスの活用で接客を促 し，コンパクトなプランで家事の効率化を図ることが可能である。

最後に, シニアタウン化した住宅地における高齢者の居住環境に 関する一連の研究を総括すると，次のことがいえる。

自然に恵まれた環境に建つ別荘に定住した高齢夫婦は個人の自立 生活を満喫しながら夫婦協力のもと他者との交流を持つ居住スタイ ルを果たし, 地域での趣味活動やボランティア活動を介して, 新た に居住ネットワークを築いている。また居住サポートを担う住民組 織を結成し, 完備された共用施設で活動し, 居住マネジメントを行 う管理会社の支援を受けるという居住システムが確立している。そ して個人のつながりと組織での支え合いをコントロールするキーパー ソンによって地域コミュニティが活性化され，さらに居住と福祉が結 びついたサポートサービスを実践する管理体制が充実されると, 居 住の安心と安全が得られ, 居住継続可能な環境が構築されるといえ るだろう。

\section{謝辞}

本研究は, 科研費基盤研究 C (JP20560586) および住宅総合 研究財団 (NO.0815) より助成を受けた。ここに記して謝意を表し ます。
注

注 1) 本研究は, 多くの健康で活動的な高齢者が新規に移住することにより, 高齢者人口が増加し，結果的に高齢者が集まって暮らす住宅地になった 別荘地, シニアタウンなどを「シニアタウン化した住宅地」と定義して いる。参考文献 4) 参照

注 2) 本研究では, 定住の根拠を, 自治会や管理会社が「定住者」として 把握しているもの, としている。な扬, 自治会や管理会社は, 居住者 の自治会加入, 住民票移動等により,「定住」を確認している。

注 3）本研究の調查対象は別荘地のほかにシニアタウンも含めるが, ここでは 便宜的に「別荘地」と一括して称している。

注 4）筆者らは、高齢者の年齢を「シルバーステージ」として、60歳未満 を stage0、60〜64 歳を stage 1、65〜69 歳を stage2、70〜 74 歳を stage3、75 79 歳を stage4、80 歳以上を stage 5 に分類している。なお, 住戸単位でみる場合は, 夫の年齢を基準にシルバーステージを設定し ている。参考文献 5）ほか

注 5）参考文献 4）6）

注 6）詳細は参考文献 4）を参照

注 7）平成 20 年度の総務省住宅土地統計調査によると, 全国平均の床面積は $94.9 \mathrm{~m}^{2}$, 居室数は 4.68 室である。

注 8) 前述の調查によると, 全国の一戸建は平家建が $9 \%, 2$ 階建が $57 \%$ ある。

注 9）生活時間の調査は, 回答者の実感に基づいたもの（MDRT 調査）で, 本 人の主観的な回答が心理状態を表すと捉えている。

注 10）一日の生活リズムを刻む食事時刻を基に時間帯を分類し，朝食以前 を「朝」, 朝食と昼食の間を「午前」, 昼食と夕食の間を「午後」, 夕 食以後を「夜」と設定する。

注 11）参考文献 7) 参照

注 12）本報では対象を自立夫婦に限定したが，本研究では単身者や要支援者 も対象にしている。ちなみに単身者は 41 人, 介護認定を受けている者 は 20 人であった。

注 13）介護相手の質問はかしま野居住者には行っていないため、対象は 75 世 帯 150 人である。

注 14）近所づきあいの詳細については、その 2 参照。参考文献 6)

\section{参考文献}

1）加藤田歌・上野淳 : 生活スタイルと住まい方からみた団地居住高齢者の 環境整備に関する考察 多摩ニュータウン団地高齢者の生活像と居住環境 整備に関する研究その 2, 日本建築学会計画系論文集第 617 号, pp.9-16, 2007.7

2） 沢田知子：熟年・高齢期におけるライフスタイルと住まい方の特徴 長寿 社会におけるライフコースの充実・支援にむけた住宅計画その 1 , 日本建 築学会計画系論文集第 547 号,pp.95-102, 2001.9

3）加茂みどり・高田光雄：「エンプティ・ネスト」期への移行に伴う住ま い方と住ニーズの変化に関する居住実験一実験集合住宅 NEXT21「安ら ぎの家」を対象として一, 日本建築学会計画系論文集第 621 号, pp.1-8, 2007.1

4）竹田喜美子・番場美恵子：開発プロセスと立地環境抢よび管理体制からみ るシニアタウン化した住宅地における居住システムの構築－別荘地と定住 地の二面性を有するシニアタウン化した住宅地における高齢者の居住環境 に関する研究その 1 -, 日本建築学会計画系論文集第 695 号, pp.29-37, 2014.1

5）番場美恵子・竹田喜美子：都市集合住宅居住の自立高齢者における「個」 を中心とした住まい方の変容過程ーシルバーステージからみた高齢期の 居住環境に関する研究その $1-$, 日本建築学会計画系論文集第 529 号, pp.25-31, 2005.6

6）竹田喜美子・番場美恵子：シニアタウン化した住宅地における居住ネッ トワークの構築と地域コミュニティの形成一別荘地と定住地の二面性を有 するシニアタウン化した住宅地に扔ける高齢者の居住環境に関する研究そ の 2 -, 日本建築学会計画系論文集第 721 号, pp.529-539, 2016.3

7）正高信男：老いはこうしてつくられる こころとからだの加齢変化, 中 公新書, 2000

8）鈴木成文・上野千鶴子・山本理顕ほか：「51C」家族を容れるハコの戦後 と現在, 平凡社, 2004.10

9）上野淳：高齢社会に生きる一住み続けられる施設と街のデザイン一, 鹿島 出版会, 2005.11

10） NHK 放送文化研究所編：日本人の生活時間・2005 - NHK 国民生活時 間調查 - , 日本放送出版協会, 2006.12 


\title{
LIFESTYLES AND ACTIVITIES OF INDEPENDENT ELDERLY COUPLES \\ AT SENIOR CITIZEN TOWNS AS VIEWED FROM THEIR HOUSING AND LIVING STYLES
}

A study on the residential environment of elderly settlers of a residential area that changed into a town for senior citizens and that has bilateral character of a villa and settlement Part 3

\author{
Kimiko TAKEDA* and Mieko BAMBA** \\ * Prof. Emeritus, Showa Women's University, Ph. D. \\ ** Lect., Dept. of Environmental Science and Design, Showa Women's University, Ph. D.
}

\begin{abstract}
The purpose of this study is to gather knowledge about sustainable residential environments for independent elderly settlers via an examination of a residential area that changed into a town for senior citizens and that has bilateral character of villa and settlement, by analyzing the lifestyle activities of resident couples from various viewpoints.
\end{abstract}

In Part 3, we investigate the lifestyle activities of independent elderly couples at the residential areas from an examination of their housing and lifestyle activities. The living style targeted in this paper is defined as the living conditions formed by three aspects: people, space, and activities. Specifically, "people" refer to the elderly couples, space is the villa (which is blessed with an abundance of nature), and activities are the lifestyle activities enjoyed in the dwelling unit.

This study was able to clarify the following:

1. Most of the seniors' life activities, except for sleep and some hobbies, are spent in spacious living-dining-kitchen (LDK) rooms and on the villa terrace, which can be used as an extension to indoor living. While their primary living space is the "LDK", they often create hobby rooms as secondary locations where they can fulfill self-realization goals.

2. The time allocations of couples (except for sleep and meals) differ for each person, with husbands spending significantly less time for housework and much more for hobbies and relaxation. In contrast, their wives' time tends to be equally divided among housework, relaxation, and hobby activities. Thus, while dining together sets the life rhythm of their days, hobbies and relaxation times are enjoyed separately, even though they will also share some household chores. Thus, couples tend to balance their married life between private and shared time.

3. It can be said that simple, compact, and open villas provide suitable housing for elderly people, because they offer the small number of functions required by couples, ease of maintenance, and the ability to accommodate lifestyle changes. Living spaces are harmonized by an open living and dining room (LD) and a spacious terrace, which provide a common venue for individuals, couples, and guests to socialize. Thus, it can be said that their lives are stably balanced by appropriate levels of privacy and communication with others. The authors have named this "harmonized life".

4. Looking at independent elderly couples from the viewpoint of "silver stage" (age level), we find they can be divided into three level: the zero to second stage ( 55 to 69 years old), the third stage (70 to 74 years old), and the fourth to fifth stage (more than 75 years old). People of the zero to second stage are full of energy and enjoy active life-centered hobbies, while the third stage is the period of transition from active to tranquil lifestyles and hobbies, and reflects their declining power. Persons in the fourth to fifth stages lead mostly placid lifestyles, with less time spent in hobbies due to their decreasing strength.

(2016 年 10 月 7 日原稿受理, 2017 年 3 月 6 日採用決定 